\title{
Horizontal distributions of aerosol constituents and their mixing states in Antarctica during the JASE traverse
}

\author{
K. Hara ${ }^{1}$, F. Nakazawa ${ }^{2}$, S. Fujita ${ }^{2}$, K. Fukui ${ }^{2, *}$, H. Enomoto ${ }^{3,{ }^{* *}}$, and S. Sugiyama ${ }^{4}$ \\ ${ }^{1}$ Department of Earth System Science, Faculty of Science, Fukuoka University, Fukuoka, Japan \\ ${ }^{2}$ National Institute of Polar Research, Tokyo, Japan \\ ${ }^{3}$ Kitami Institute of Technology, Kitami, Japan \\ ${ }^{4}$ Institute of Low temperature Science, Hokkaido University, Sapporo, Japan \\ *now at: Tateyama Caldera Sabo Museum, Toyama, Japan \\ ** now at: National Institute of Polar Research, Tokyo, Japan \\ Correspondence to: K. Hara (harakei@ fukuoka-u.ac.jp)
}

Received: 26 March 2014 - Published in Atmos. Chem. Phys. Discuss.: 7 May 2014

Revised: 19 August 2014 - Accepted: 24 August 2014 - Published: 25 September 2014

\begin{abstract}
Measurements of aerosol number concentrations and direct aerosol sampling were conducted on continental Antarctica during the traverse of the Japanese-Swedish joint Antarctic expedition (JASE) from 14 November 2007 until 24 January 2008. Aerosol concentrations in background conditions decreased gradually with latitude in inland regions during the traverse. The lowest aerosol number concentrations were $160 \mathrm{~L}^{-1}$ in $D_{\mathrm{p}}>0.3 \mu \mathrm{m}$, and $0.5 \mathrm{~L}^{-1}$ in $D_{\mathrm{p}}>2 \mu \mathrm{m}$. In contrast, aerosol concentrations reached $3278 \mathrm{~L}^{-1}$ in $D_{\mathrm{p}}>0.3 \mu \mathrm{m}$, and $215 \mathrm{~L}^{-1}$ in $D_{\mathrm{p}}>2 \mu \mathrm{m}$ under strong wind conditions. The estimated aerosol mass concentrations were $0.04-5.7 \mu \mathrm{g} \mathrm{m}^{-3}$. Single particle analysis of aerosol particles collected during the JASE traverse was conducted using a scanning electron microscope equipped with an energy dispersive $x$ ray spectrometer. Major aerosol constituents were sulfates in fine mode, and sulfate, sea salts, modified sea salts, and fractionated sea salts in coarse mode. K-rich sulfates, Mg-rich sulfate, Ca-rich sulfates, and minerals were identified as minor aerosol constituents. Horizontal features of $\mathrm{Cl} / \mathrm{Na}$ ratios imply that sea-salt modification (i.e. $\mathrm{Cl}$ loss) occurred on the Antarctic continent during the summer. Most sea-salt particles in the continental region near the coast were modified with acidic sulfur species such as $\mathrm{H}_{2} \mathrm{SO}_{4}$ and $\mathrm{CH}_{3} \mathrm{SO}_{3} \mathrm{H}$. By contrast, acidic species other than the acidic sulfur species (likely $\mathrm{HNO}_{3}$ ) contributed markedly to sea-salt modification in inland areas during the traverse. Mg-rich sea-salt particles and $\mathrm{Mg}$-free sea-salt particles were present in coarse and fine modes from the coast to inland ar-
\end{abstract}

eas. These sea-salt particles might be associated with sea-salt fractionation on the snow surface of continental Antarctica.

\section{Introduction}

Atmospheric aerosol constituents in Antarctic regions have been measured for more than 3 decades to elucidate the regions' aerosol chemistry, to monitor Earth background levels, and to interpret ice core records (Savoie et al., 1992, 1993; Minikin et al., 1998; Legrand et al., 2001; Hara et al., 2004; Weller et al., 2011). Although most investigations of aerosol chemistry have been conducted at coastal stations such as Syowa Station, Neumayer Station, Halley Station, Dumont d'Urville Station, and Mawson Station (Savoie et al., 1992, 1993; Legrand et al., 2001; Hara et al., 2004; Weller et al., 2011), aerosol chemistry and atmospheric chemistry have been investigated recently even at inland stations such as Amundsen-Scott (South Pole) Station, Dome F Station, Kohnen Station, and Concordia (Dome C) Station (Bodhaine, 1995; Hara et al., 2004; Weller and Wagenbach, 2007; Jourdain et al., 2008; Eisele et al., 2008; Udisti et al., 2012).

From those earlier investigations, basic aerosol chemical properties were obtained: seasonal features of the concentrations of major aerosol constituents $\left(\mathrm{SO}_{4}^{2-}, \mathrm{CH}_{3} \mathrm{SO}_{3}^{-}\right.$, $\mathrm{NO}_{3}^{-}$, and sea salts (e.g., $\mathrm{Na}^{+}$and $\left.\mathrm{Cl}^{-}\right)$), and minor aerosol constituents (minerals and carbonaceous species (soot and 
organics)) at Antarctic coasts and inland area. In those investigations, aerosol constituents were determined using bulk analysis techniques (mainly ion chromatography). Such techniques, however, cannot provide sufficient information about the mixing states of respective aerosol constituents. That information is necessary to elucidate the origins of constituents and the chemical reactions that occur on aerosol particles (heterogeneous reactions). For sample analysis, single particle analysis takes longer than bulk analysis. Therefore, few previous investigations have used single particle analysis (Parungo et al., 1979; Yamato et al., 1987a, b; Artaxo et al., 1992; Mouri et al., 1999; Hara et al., 1995, 2005, 2013).

Previous investigations (e.g., Savoie et al., 1992, 1993; Minikin et al., 1998; Hara et al., 2004, 2013) showed that major aerosol constituents in Antarctic atmosphere near surface were sulfates (probably $\mathrm{H}_{2} \mathrm{SO}_{4}$ ) in summer and sea salts in the winter-spring period. Actually, $\mathrm{SO}_{4}^{2-}$ and $\mathrm{CH}_{3} \mathrm{SO}_{3}^{-}$ are strongly dominant during the summer in Antarctica because of biogenic activity in the ocean (e.g., Minikin et al., 1998; Legrand et al., 2001). Size segregated aerosol analysis showed that $\mathrm{SO}_{4}^{2-}$ and $\mathrm{CH}_{3} \mathrm{SO}_{3}^{-}$were distributed mainly in the sub-micrometre range at the Antarctic coasts (e.g., Jourdain and Legrand, 2001; Read et al., 2008). Yamato et al. (1987a, b) used chemical testing (Ca thin-film method) to demonstrate that sulfuric acid was dominant in aerosol constituents in the Antarctic troposphere during summer. In addition, single particle analysis using laser microprobe mass spectrometry showed that $\mathrm{CH}_{3} \mathrm{SO}_{3}^{-}$was mixed internally with sulfate particles (probably $\mathrm{H}_{2} \mathrm{SO}_{4}$ particles) near the surface on the Antarctic coasts during summer (Wouters et al., 1990; Hara et al., 1995).

Sea-salts are dominant during winter-spring (e.g., Hara et al., 2004). Sea-salt particles were distributed widely in ultrafine-coarse mode throughout the year at Syowa Station (Hara et al., 2010a, 2011a) and were distributed in fine-coarse mode during the summer at Aboa Station (Kerminen et al., 2000; Teinilä et al., 2000). From elemental analysis of individual particles using Energy dispersive $X$ ray spectrometer (EDX), Mouri et al. (1999) and Hara et al. (2005, 2013) reported that sea-salt particles near the surface were modified with $\mathrm{SO}_{4}^{2-}$ and $\mathrm{CH}_{3} \mathrm{SO}_{3}^{-}$during the summer, and were modified with $\mathrm{NO}_{3}^{-}$in August at Syowa Station. Furthermore, single particle analysis of aerosol particles collected using tetheredballoon operations exhibited seasonal and vertical features of aerosol constituents and their mixing states in near surface - lower free troposphere $(2.5 \mathrm{~km})$, sea-salt modification, and sea-salt fractionation (Hara et al., 2013). In addition to sea-salt modification, sea-salt particles were fractionated through precipitation of several salts such as mirabilite $\left(\mathrm{Na}_{2} \mathrm{SO}_{4} 10 \mathrm{H}_{2} \mathrm{O}\right)$ and hydrohalite $\left(\mathrm{NaCl} 2 \mathrm{H}_{2} \mathrm{O}\right)$ in sea ice formation and frost flower appearance under colder conditions (e.g., Wagenbach et al., 1998; Rankin et al., 2000, 2002; Hara et al., 2004, 2012). Sea-salt fractionation on sea ice (including frost flowers) by depletion of $\mathrm{Na}$ salts engenders
$\mathrm{Mg}$ enrichment in sea-salt particles during winter-spring on the Antarctic coast (Hara et al., 2010a, 2012, 2013). Furthermore, Hara et al. (2013) pointed out the likelihood that seasalt fractionation (Mg separation in sea-salt particles) occurs during summer. The following questions, however, remain.

1. Where does sea-salt fractionation occur on the Antarctic regions during summer?

2. What are the specific processes of sea-salt fractionation (Mg separation)?

Although useful and important knowledge related to aerosol chemical properties (e.g., concentrations, and mixing states) has been obtained gradually from previous investigations using bulk and single-particle analysis of aerosol particles along the Antarctic coasts, a great dearth of knowledge remains for aerosol chemical properties and chemical processes taking place on the Antarctic continent. To elucidate spatiotemporal features of glaciological environment and atmospheric quality in Queen Maud Land, East Antarctica, scientific traverse using snow vehicles was conducted by a Japanese Swedish Antarctic Expedition (JASE) in the austral summer of 2007/2008 (Fujita et al., 2011). In this study, measurements of the aerosol number concentrations and direct aerosol sampling were conducted during the JASE traverse to characterize and elucidate the horizontal features of aerosol constituents and their mixing states in the atmosphere near the ground on the Antarctic continent during summer. Herein, we mainly discuss (1) the horizontal distributions of aerosol constituents and mixing states on the Antarctic continent during summer, (2) sea-salt modification, and (3) seasalt fractionation.

\section{Aerosol measurements and data analysis}

\subsection{JASE traverse}

Figure 1 depicts the JASE traverse route in Queen Maud Land, East Antarctica. On this campaign, the Japanese team travelled from S16 on the Antarctic continent (near Syowa Station) to a meeting point on the Antarctic plateau via Dome F Station. The Swedish team travelled from Wasa Station to the meeting point via Kohnen Station. Aerosol measurements and direct aerosol sampling for this study were conducted during the Japanese team traverse. The Japanese traverse team left from S16 on 14 November 2007, and arrived at the meeting point on 27 December 2007 in the incoming traverse. After some joint scientific work at the meeting point was conducted for several days, the outgoing traverse (return to S16) began on 30 December 2007. During the outgoing traverse, the Japanese team travelled from the meeting point to Dome F on the southern side of the ice divide for glaciological measurements. The team approached S16 on 24 January 2008. Details of the traverse were described by Fujita et al. (2011). 


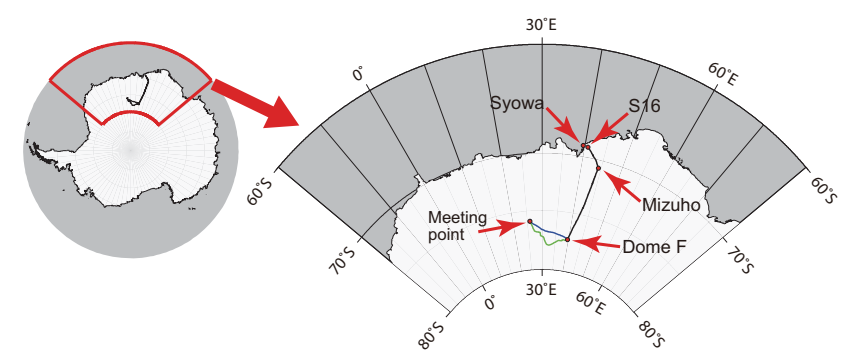

Figure 1. Traverse routes of Japanese team during JASE campaign. Black lines represent traverse routes between S16 and Dome F in incoming and outgoing traverse. The blue line represents the traverse route from Dome $\mathrm{F}$ to meeting point in the incoming traverse. The red line represents traverse route from the meeting point to Dome $\mathrm{F}$ in outgoing traverse. The traverse route of the Swedish team was depicted in Fujita et al. (2011).

\subsection{Meteorological measurements during the JASE traverse}

Continuous measurements of air pressure (F4711; Yokogawa Analytical Systems Inc.), air temperature (KDC-A01-S001 and KADEC21-U4; Kona System Inc.), wind speed, and wind direction (KADEC21-KAZE; Kona System Inc.) were performed during the JASE traverse. Meteorological sensors were fixed on the snow vehicle, located approximately at $3 \mathrm{~m}$ above the snow surface. Daily meteorological observations (air, pressure, air temperature, wind direction, wind speed, weather, visibility, degree of cloud cover, and cloud type) were made around 15:00 LT. Weather conditions were observed also during aerosol measurements conducted at camp sites.

\subsection{Aerosol measurements}

Aerosol measurements and direct aerosol sampling were conducted during the JASE traverse. For safe operation of aerosol measurements, measurements of the aerosol size distribution, and direct aerosol sampling were not made during the traverse during the daytime but were conducted only at camp sites.

\subsubsection{Measurements of aerosol number concentrations}

Aerosol number concentrations were measured using a portable optical particle counter (OPC, KR12A; Rion Co. Ltd.) during direct aerosol sampling at every camp site. The measurable size range was $D_{\mathrm{p}}>0.3,0.5,0.7,1.0$, 2.0 , and $5.0 \mu \mathrm{m}$. The OPC was calibrated using spherical polystyrene latex particles with refractive index of 1.590i. Consequently, the size provided from OPC is "optically Polystyrene latex (PSL)-equivalent size". The OPC packed in an insulator box was set at ca. $1 \mathrm{~m}$ above the snow surface by tripod, located on the windward side of the camp site to avoid local contamination (mainly exhaust from snow ve- hicles). Aerosol number concentrations were recorded with resolution of every $23-25 \mathrm{~s}$ (corresponding to $1 \mathrm{~L}$ air sucking) during direct aerosol sampling. The ambient number concentrations were converted to concentration under standard conditions $\left(0^{\circ} \mathrm{C}\right.$ and $\left.1013.25 \mathrm{hPa}\right)$.

\subsubsection{Direct aerosol sampling and analysis}

Aerosol particles were collected on carbon-coated collodion thin film supported by Ni micro-grid (square-300 mesh; Veco Co.) using a two-stage aerosol impactor. The cut-off diameters of the impactor were 2.0 and $0.2 \mu \mathrm{m}$ in aerodynamic diameter at a flow rate of $1 \mathrm{~L} \mathrm{~min}^{-1}$. The aerodynamic diameter was estimated for particles density of $1 \mathrm{~g} \mathrm{~cm}^{-3}$. The aerosol particle density, however, is mostly larger than $1 \mathrm{~g} \mathrm{~cm}^{-3}$, for instance, $\mathrm{NaCl}\left(2.2 \mathrm{~g} \mathrm{~cm}^{-3}\right)$, and $\mathrm{H}_{2} \mathrm{SO}_{4}\left(1.84 \mathrm{~g} \mathrm{~cm}^{-3}\right)$. Therefore, aerosol particles slightly smaller than the cut-off diameter (aerodynamic diameter) can be collected on the sample substrates, depending on the particle density. The impactor was set at ca. $1 \mathrm{~m}$ above the snow surface next to the OPC. Because of the lower aerosol number concentrations on the Antarctic continent, direct aerosol sampling was conducted for 28-86 min (mean, $60 \mathrm{~min}$ ) depending on the aerosol number concentration. After direct sampling, aerosol samples were kept in air tight boxes including desiccant until analysis in our laboratory in Japan to avoid humidification that can engender morphological change, modification (chemical reactions), and fractionation, as described by Hara et al. (2002, 2005, 2013). Therefore, aerosol modification and fractionation might be negligible, although aerosol constituents can be solidified separately in each aerosol particle because of efflorescence of deliquescent aerosol particles under dry conditions.

Individual aerosol particles on the sample substrate were observed and analyzed in this study using a scanning electron microscope equipped with an energy dispersive $x$ ray spectrometer (SEM-EDX; Quanta FEG-200F, FEI; XL30; EDAX Inc.). Analytical conditions were the following: $20 \mathrm{kV}$ accelerating voltage and $30 \mathrm{~s}$ counting time. To avoid analytical bias of localization of aerosol constituents in each particle, the rectangular or square area almost covering a particle was scanned using an electron beam in EDX analysis. The analytical depth in SEM-EDX analysis depends on the accelerating voltage, chemical composition, density, and other factors. Although secondary electrons can be emitted from a depth of several $\sim 10 \mathrm{~nm}$ (e.g., Ding et al., 2009), characteristic $x$ rays can be emitted from a depth of a few $\mu$ m (e.g., Goldstein et al, 2003). Most of the coarse particles examined in this study were smaller than $3 \mu \mathrm{m}$ in diameter. Consequently, characteristic $x$ rays were obtained from whole particle in fine and coarse mode in this study. When the particle thickness is larger than ca. $5 \mu \mathrm{m}$, compositions near surface (thickness of a few micrometres) might be detected. However, only a few particles larger than $5 \mu \mathrm{m}$ were found in a single sample. Details of analytical procedures and data quality were described 
by Hara et al. $(2002,2005,2013)$. We analyzed 2690 particles in coarse mode (mean: 58 particles / sample) and 45,044 particles in fine mode (mean: 961 particles/sample). Most aerosol-sampled areas on the substrates were analyzed in coarse mode in this study. Although we attempted to analyze as many coarse particles as possible, the lower aerosol number concentrations in coarse mode limit the number of the analyzed aerosol particles in this study. However, 20-30\% of the aerosol-sampled area on the substrates was analyzed in aerosol samples in fine mode.

\section{Results and Discussion}

\subsection{Meteorological conditions during the JASE campaign}

\subsubsection{Air temperature, wind speed, and weather near the surface}

Figure 2 shows variations of latitude, elevation, air temperature, and wind speed during the JASE traverse of the Japanese team. The air temperature decreased gradually with latitude in $69-73^{\circ} \mathrm{S}$ in both the incoming and outgoing traverse, although the highest temperature near the coast was ca. $-7.6^{\circ} \mathrm{C}$ in the incoming traverse and $-2.9^{\circ} \mathrm{C}$ in the outgoing traverse. By contrast, the air temperature was around $-30^{\circ} \mathrm{C}$ at latitudes higher than $73^{\circ} \mathrm{S}$ in this study. The lowest air temperature was $-43^{\circ} \mathrm{C}$. In addition, air temperature showed strong diurnal variation. The diurnal temperature range was approximately $8.6^{\circ} \mathrm{C}$ on average (maximum, $\left.16^{\circ} \mathrm{C}\right)$.

Wind speed often showed diurnal features during the traverse. In addition to diurnal features of wind speed, the wind speed increased because of an approaching cyclone, for example on 18-22 November, 27-30 November, 7-8 December, and 20-23 December. Although the diurnal maximum of air temperature was observed at noon time (LT), those of wind speed were lagged at latitudes lower than $73^{\circ} \mathrm{S}$. Similarly, similar diurnal variations of wind speed were observed on Antarctic continent (Allison, 1998; Van As et al., 2005) and Antarctic coasts (Sato and Hirasawa, 2007). However, the diurnal maxima of wind speed were mutually synchronized well to those of air temperature at latitudes higher than $74^{\circ} \mathrm{S}$, when their diurnal features occur. According to a manual weather check at every camp site, the weather was mostly clear and fine. When the wind speed was greater than ca. $6 \mathrm{~m} \mathrm{~s}^{-1}$, drifting snow prevailed during the traverse, for example on 28-29 November, 7 December, and 21-23 December.
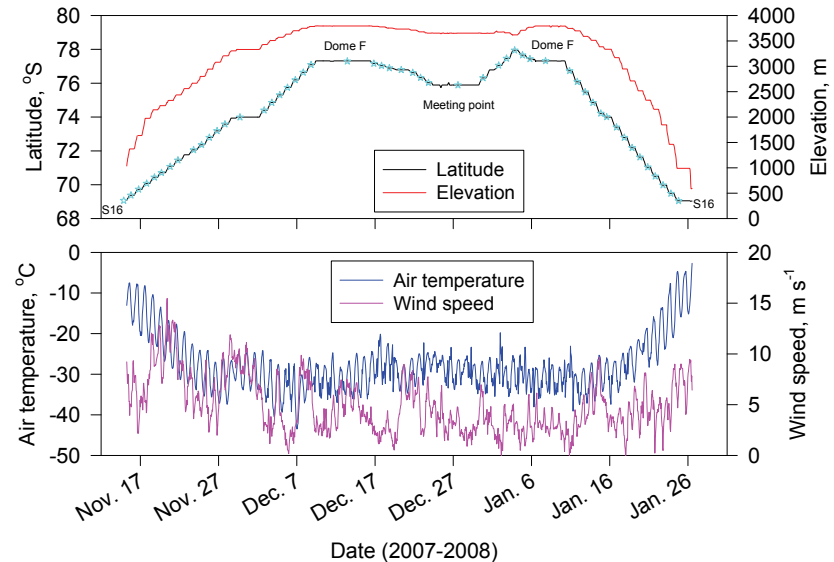

Figure 2. Variations of latitudes, elevation, air temperature, and relative humidity during the JASE traverse. Cyan stars represent dates and locations of aerosol measurements and direct sampling.

\subsubsection{Air mass history during the JASE traverse}

To elucidate the history and origins of air masses observed in this study, the 5-day backward trajectory was computed using the reanalysis data by National Centers for Environmental Prediction (NCEP) and vertical motion mode in this study (Draxler and Rolph, 2013). Uncertainty of the trajectory analysis derives from the resolution of meteorological data (wind field), calculation scheme, and trajectory model. Kahl et al. (1989) and Stohl et al. (1995) reported that error reached hundreds to $1000 \mathrm{~km}$ after trajectory calculation for 5 days. Therefore, the 5-day backward trajectory was analyzed in this study. Indeed, previous works (Reijmer and van den Broeke, 2001; Reijmer et al., 2002; Hara et al., 2004, 2013; Suzuki et al., 2008) used 5-day backward trajectory analysis to elucidate the origins of moisture and aerosols. In general, uncertainty can be greater when the starting altitude of trajectories is within in boundary layer. The 5-day backward trajectories from altitudes in the boundary layer free troposphere, however, were closely consistent well with vertical profiles of aerosol constituents over Syowa Station, Antarctica (Hara et al., 2013). For the present study, we calculated the trajectories from 200,500 , and $1000 \mathrm{~m}$ above ground level. The trajectories showed similar vertical features and transport pathways in most cases, so that a 5-day backward trajectory might be applied to discuss air mass history even in the Antarctic continent.

Figure 3 depicts backward trajectories from $200 \mathrm{~m}$ above ground level over each camp site. As depicted in Fig. 3a, air masses from the camp sites located in $69-71^{\circ} \mathrm{S}$ in the incoming traverse were transported westward along with Antarctic coastal line during the 5 days prior. Vertical features of the backward trajectories imply that these air masses travelled in the upper boundary and lower free troposphere. In contrast to the transport pathway in $69-71^{\circ} \mathrm{S}$, air masses at the camp 

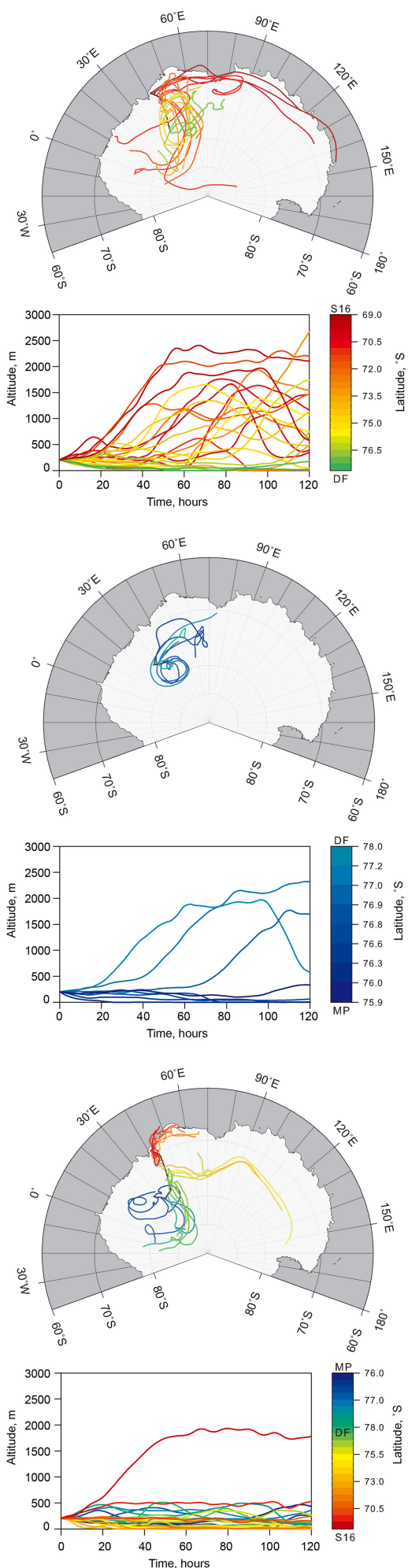

Figure 3. 5-day backward trajectories from every camp site in (a) incoming traverse from S16 to Dome F, and (b) traverse from Dome $\mathrm{F}$ (DF) to meeting point (MP), (c) traverse from meeting point to S16 in outgoing traverse. Black lines show the traverse route. Altitudes denote the height above the ground. Colour code corresponds to the latitude at starting points of the trajectory. sites in $>71^{\circ} \mathrm{S}$ travelled in the free troposphere over the Antarctic continent during the 5 days prior. Air masses in the traverse from Dome $\mathrm{F}$ to the meeting point flowed over the Antarctic plateau during the 5 days prior (Fig. $3 \mathrm{~b}$ ). The vertical motions in these air masses were classified into (1) transport from the free troposphere and (2) travel in the boundary layer (near surface). Compared to the weather at camp sites, the first type (transport from free troposphere) and second type (transport in the boundary layer) corresponded to days with good weather, and to days with strong winds and drifting snow conditions. Backward trajectories in the outgoing traverse from the meeting point to Dome $\mathrm{F}$ indicate transport in the boundary layer - lower free troposphere over the Antarctic continent (Fig. 3c). The transport pathway during the outgoing traverse from Dome F to S16 was clearly divisible into transport from coastal areas and transport over the continent (Fig. 3c). Although air masses at latitudes higher than $73^{\circ} \mathrm{S}$ travelled over the continent, air masses at $>75^{\circ} \mathrm{S}$ and at $73-75^{\circ} \mathrm{S}$ were transported from near the South Pole, and were transported along ice ridges through near Dome A and Dome $\mathrm{C}$ in East Antarctica. Furthermore, air masses in the outgoing traverse moved near ground level (probably in the boundary layer) for the past 5 days, in contrast to the large variation of vertical motions in the incoming traverse from S16 to Dome F. These features of transport pathways of air masses on the Antarctic continent during the JASE traverse showed good agreement with seasonal variations of the air mass origins and transport pathway over the Antarctic continent by Suzuki et al. (2013).

\subsection{Number concentrations, mass concentrations, and size distribution of aerosol particles during the JASE traverse}

Figures 4 and 5 depict features of wind speed, the aerosol number concentrations, Junge slope, and aerosol mass concentrations during direct aerosol sampling at each camp site during the JASE traverse. During the incoming traverse, the aerosol number concentrations decreased gradually with latitude and elevation, except high number concentrations in strong winds. Higher aerosol number concentrations were identified under conditions with wind speeds higher than $6 \mathrm{~m} \mathrm{~s}^{-1}$ in this study. Therefore, we use aerosol concentrations at wind speeds lower than $6 \mathrm{~m} \mathrm{~s}^{-1}$ as "background aerosol concentrations" in this study. For instance, the background number concentrations in $D_{\mathrm{p}}>0.3 \mu \mathrm{m}$ and $D_{\mathrm{p}}>2 \mu \mathrm{m}$ changed, respectively, from ca. 1330 near the coast to ca. $160 \mathrm{~L}^{-1}$, and from 36 to $0.5 \mathrm{~L}^{-1}$. The number concentrations on the Antarctic continent during the JASE traverse were lower than those in the lower free troposphere over Syowa Station in summer (Hara et al., 2011b). The aerosol number concentrations increased considerably under strong wind and drifting snow conditions. Considering that air masses on the Antarctic continent during JASE were not transported from coastal areas during the 5 days prior, this increase suggests 

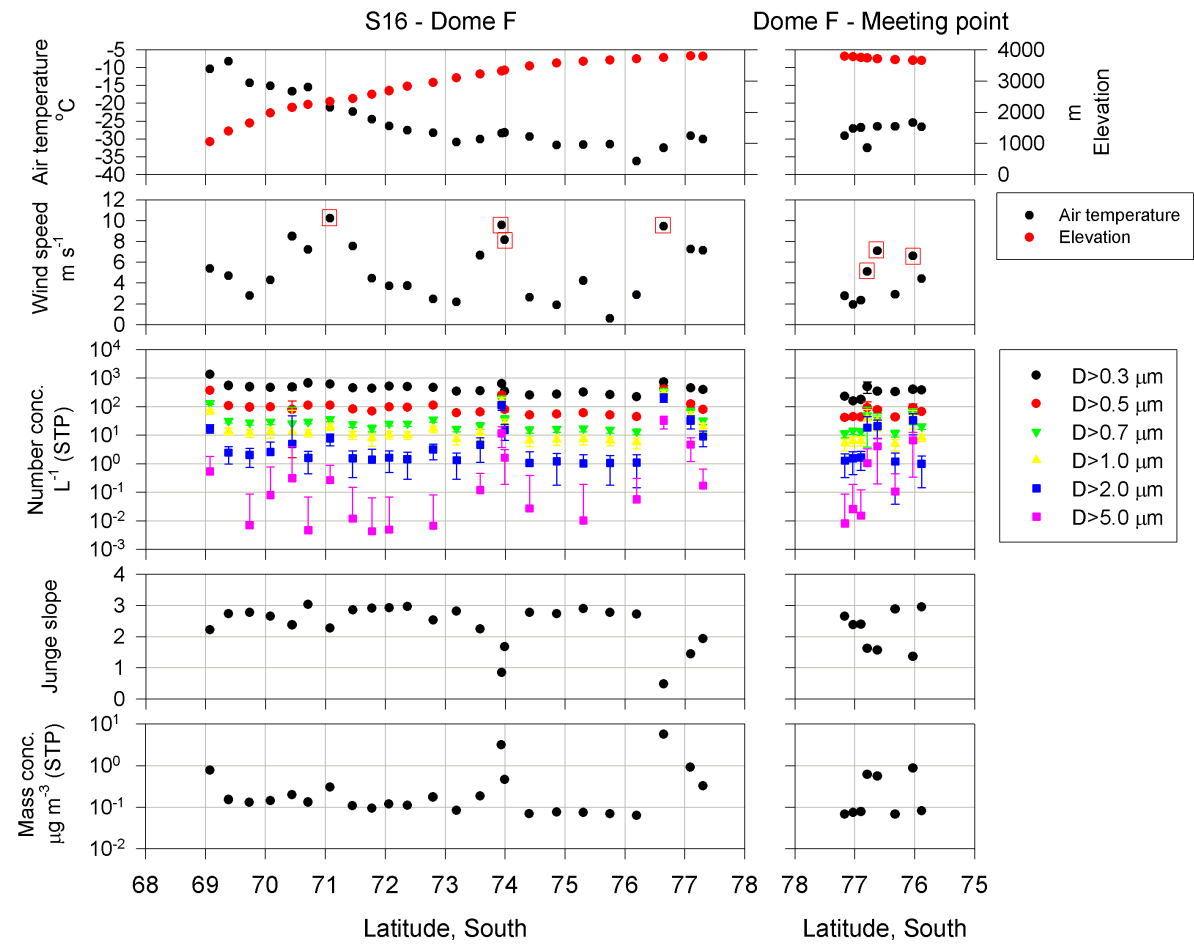

Figure 4. Horizontal features of air temperature, elevation, wind speed, aerosol number concentrations and Junge slope during incoming traverse from S16 to the meeting point. Red boxes show conditions with drifting snow.

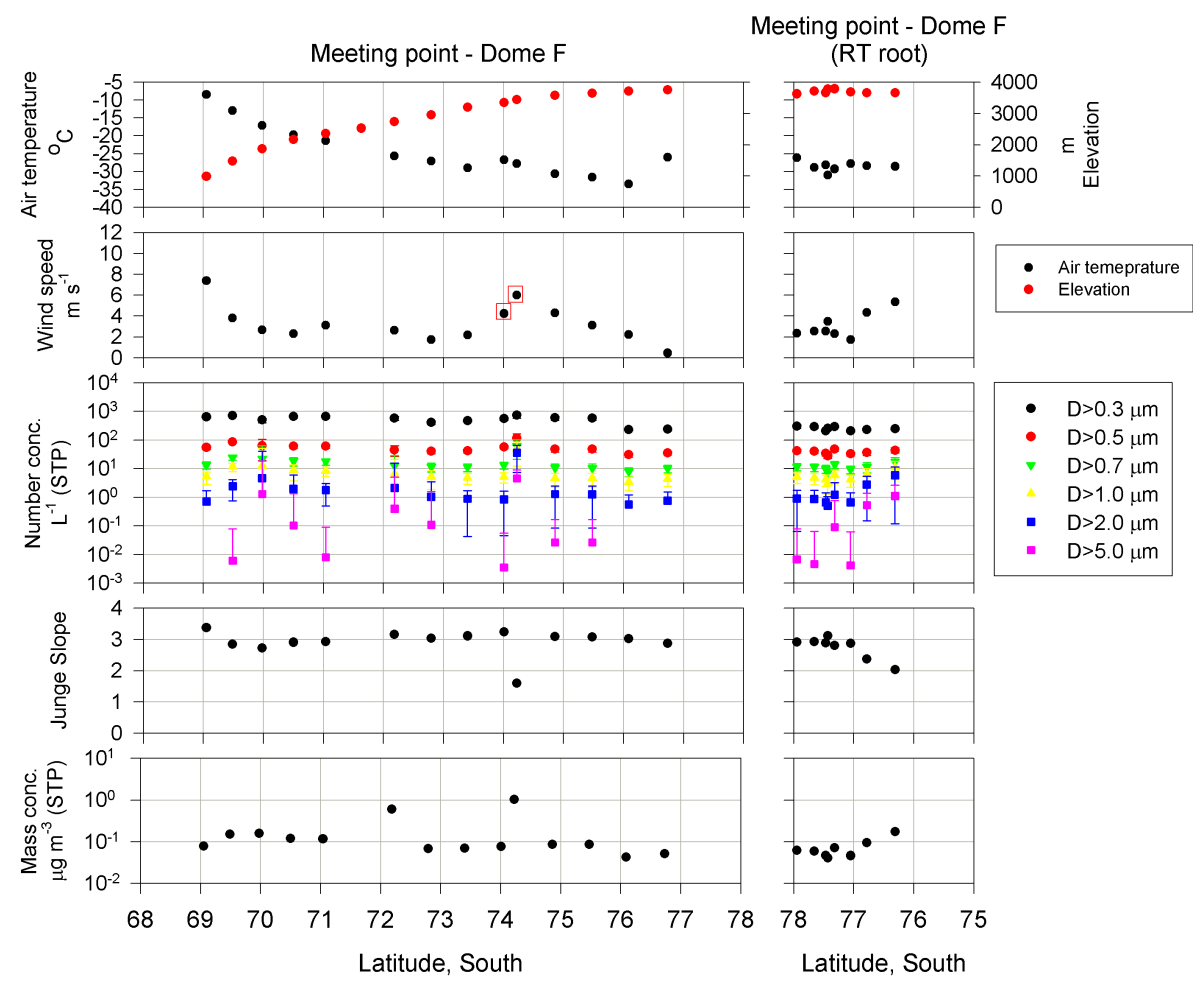

Figure 5. Horizontal features of air temperature, elevation, wind speed, aerosol number concentrations and Junge slope during outgoing traverse from the meeting point to S16. Red boxes show conditions with drifting snow. 
that strong winds engender the release of aerosol particles and small snow/ice flakes from the snow surface. Particularly the number concentrations in coarse particles having diameter larger than $2.0 \mu \mathrm{m}$ increased remarkably by $1-2$ orders of magnitude higher in strong wind conditions, as shown in Figs. 4 and 5. The aerosol number concentrations and their horizontal features in the outgoing traverse were similar to those in the incoming traverse.

For comparison of the aerosol size distribution, we estimated the "Junge slope" in this study. The aerosol size distribution in fine-coarse mode can be approximated as the following equation (Junge, 1963).

$\frac{\mathrm{d} N}{\mathrm{~d} \log D_{\mathrm{p}}}=\alpha D_{\mathrm{p}}^{-\beta}$

Therein, $\alpha$ and $\beta$ respectively represent a constant and the Junge slope. The Junge slope is often used as an index of the shape of aerosol size distribution in fine-coarse modes. For instance, higher (lower) Junge slope values are visible, respectively, in cases of high (low) number concentrations in fine mode and/or low (high) concentrations in coarse mode, respectively. In this study, the Junge slope $(\beta)$ was estimated as $0.3-5.0 \mu \mathrm{m}$ in diameter. The Junge slope was 2.22-3.03 (mean, 2.70; median, 2.75) in background conditions (wind speed lower than $6 \mathrm{~m} \mathrm{~s}^{-1}$ ) in the incoming traverse. In contrast, the Junge slope decreased to less than 2.5 under conditions with strong winds $\left(>6 \mathrm{~m} \mathrm{~s}^{-1}\right)$ or drifting snow. The Junge slope in the outgoing traverse was 2.733.37 (mean, 3.03; median, 2.92) under background conditions. Similar to the Junge slope in the incoming traverse, the Junge slope decreased in strong winds during the outgoing traverse. The considerable decrease of June slope in strong wind corresponded to high number concentrations in coarse mode (Figs. 4-5). Consequently, aerosol size distributions depended closely on the release of aerosol particles from snow surfaces by blowing winds. In addition, the Junge slopes in the outgoing traverse were slightly larger than those in the incoming traverse. This difference derived from the reduction of aerosol release (especially in coarse mode) from the snow surface under calm wind conditions during the outgoing traverse. Considering that weather conditions are usually stable in December-January on the Antarctic region (e.g., Sato and Hirasawa, 2007), these differences between the incoming traverse and outgoing traverse might reflect seasonal features of aerosol number concentrations and the size distribution on the Antarctic continent during early summer (or end-spring) through mid-summer. Compared to the Junge slope in the lower troposphere over Syowa Station during the summer (range, 2.2-3.2; median, 2.5; Hara et al., 2011b), the Junge slope was slightly greater on the Antarctic continent during the JASE traverse. The difference of the Junge slopes might result from horizontal features of the number concentrations, particularly in coarse mode, from the coasts to inland areas. Indeed, the number concentrations in coarse mode in JASE traverse were several factors - one order lower than those over Syowa Station.

Here, we attempt to estimate the mass concentrations using aerosol number concentrations measured with OPC. The spherical shape and density were assumed in the estimation. As described above, diameters in OPC are the "optically PSL-equivalent size", so that the estimated aerosol volume means "PSL-equivalent volume" in this study. The densities corresponded to those of sulfates (ca. $1.8 \mathrm{~g} \mathrm{~cm}^{-3}$ ) and $\mathrm{NaCl}$ $\left(2.2 \mathrm{~g} \mathrm{~cm}^{-3}\right)$. Major aerosol constituents were sulfate particles during JASE traverse (details are presented later herein). Therefore, we used the density of $1.8 \mathrm{~g} \mathrm{~cm}^{-3}$ to estimate the mass concentration in this study. The number concentrations of aerosol particles smaller than $0.3 \mu \mathrm{m}$ were not included in the estimation. Therefore, the estimated mass concentrations can be slightly underestimated. In addition, the aerosol number concentrations were observed using OPC above the snow surface. Consequently, the number concentrations were measured under ambient conditions (not dry conditions), although OPC had been packed in an insulator box. Therefore, the estimated mass concentrations included masses of water in aerosol particles in this study. The presence of water in aerosol particles can cause overestimation of the aerosol density and mass concentrations because of salt dilution by water.

With the exception of higher mass concentrations under conditions with drifting snow and strong winds, the aerosol mass concentrations decreased gradually from ca. 0.16 (near the coasts) to $0.04 \mu \mathrm{g} \mathrm{m}^{-3}$ (near Dome F Station). The mass concentrations on the Antarctic continent during JASE traverse were similar to the mass concentrations of water soluble aerosol constituents at Kohnen Station (Weller and Wagenbach, 2007). They were slightly higher than the mass concentrations water soluble aerosol constituents at Dome C (Preunkert et al., 2008; Udisti et al., 2012). The aerosol mass concentrations increased considerably to greater than several micrograms per cubic metre under conditions with drifting snow and strong winds. The highest mass concentrations were approximately $5.7 \mu \mathrm{g} \mathrm{m}^{-3}$. Higher mass concentrations were observed in high number concentrations in coarse mode. Therefore, aerosol particles from the snow surface by erosion under strong winds might make a substantial contribution to high aerosol mass concentrations.

Figure 3 shows that air masses on the Antarctic continent were transported over the Antarctic plateau during the 5 days prior. Considering that coarse particles can be removed efficiently from the atmosphere through dry deposition during transport, isolation from coastal regions might account for gradient features of aerosol number concentrations in coarse mode. In other words, coarse particles are supplied only slightly from coastal regions into the Antarctic plateau during summer. The aerosol number concentrations increased markedly in all size ranges $\left(D_{\mathrm{p}}>0.3 \mu \mathrm{m}\right)$ under strong wind conditions. Therefore, the wind-blowing release of aerosol particles might play an important role in 

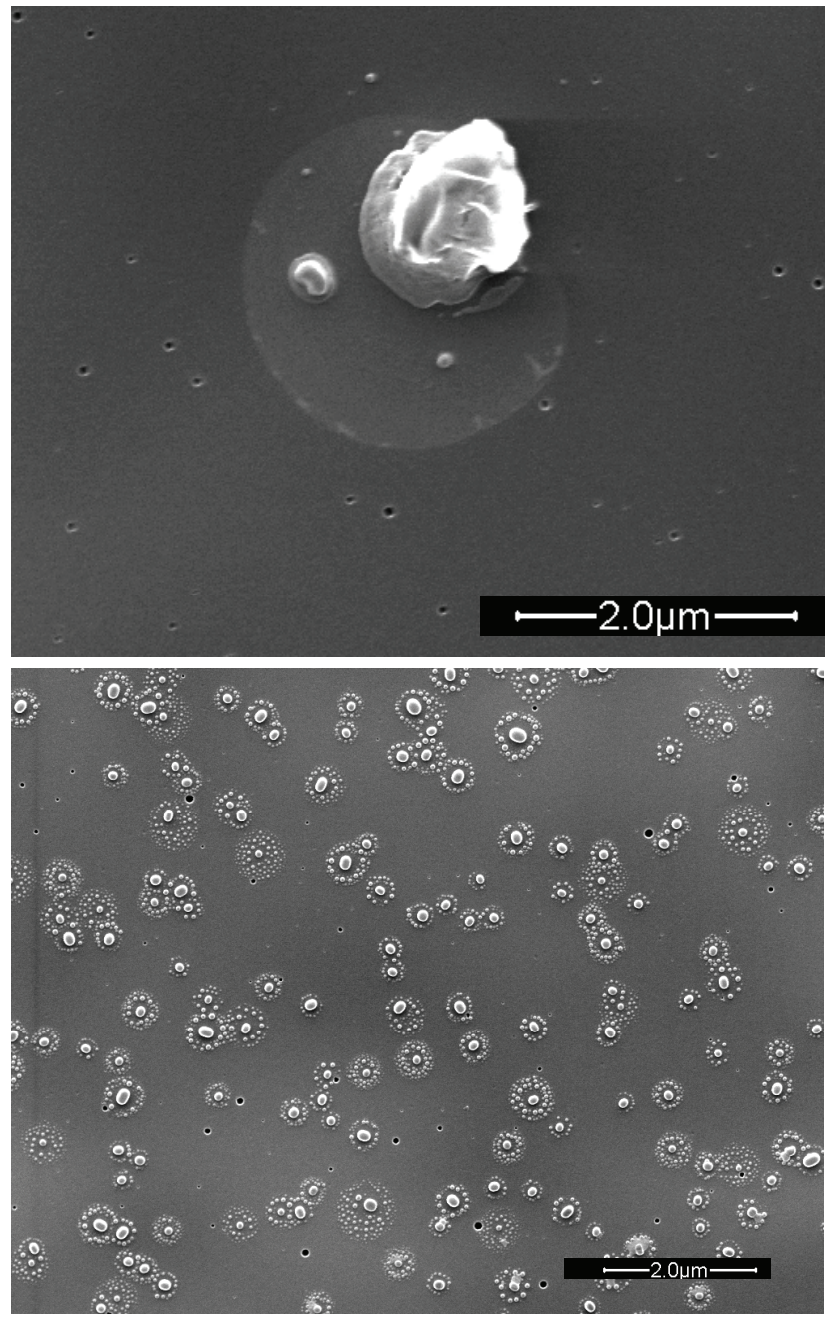

Figure 6. SEM images of aerosol particles in (a) coarse mode and (b) fine mode.

maintaining the aerosol system over the continent in addition to gas-to-particle conversion.

\subsection{Morphology of aerosol particles collected during the JASE traverse}

Figure 6 depicts examples of SEM images of aerosol particles collected during the JASE traverse. Figure 6a shows that most aerosol particles in fine mode had a satellite structure. The satellite particles were dominant in all samples in fine mode $\left(D_{\mathrm{p}}: 0.2-2 \mu \mathrm{m}\right)$. The satellite particles were often observed also in coarse mode $\left(D_{\mathrm{p}}>2 \mu \mathrm{m}\right)$ in this study. Yamato et al. (1987) used chemical tests (Ca thin film method) to show that satellite particles consisted of $\mathrm{H}_{2} \mathrm{SO}_{4}$ in the Antarctic troposphere during summer. Figure $6 \mathrm{~b}$ shows that aerosol particles without a satellite structure were also observed in coarse mode. Most non-satellite particles in coarse mode had a solid core with irregular shape and crystal-like shape. In addition, stain around the solid core was identified
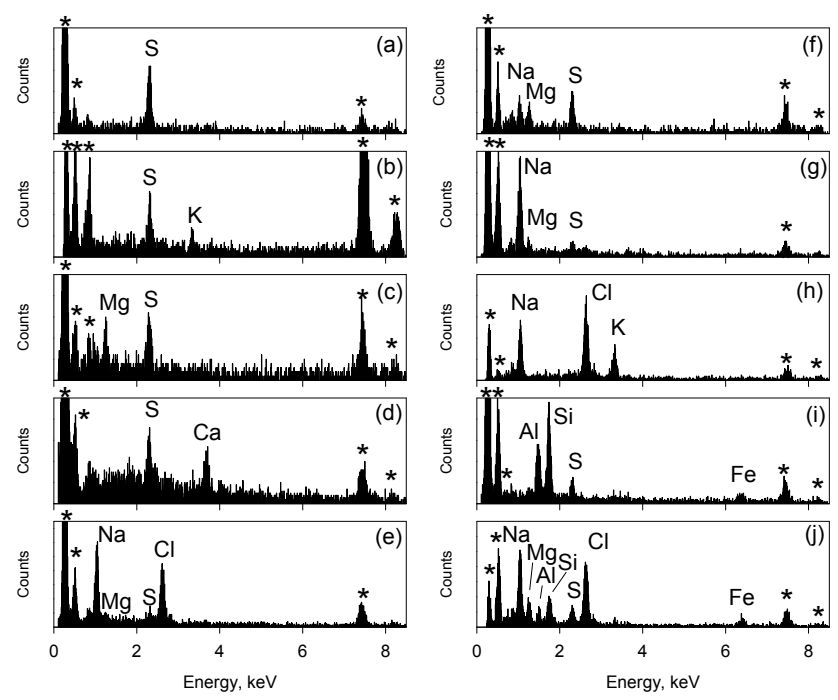

Figure 7. EDX spectra of aerosol particles collected during the JASE traverse. Asterisks denote background peaks derived from the sample substrate.

often in coarse mode, as depicted in Fig. 6b. Some coarse particles were satellite particles with irregular solid cores (not shown). Presence of the stain and satellite structure in coarse and fine modes suggests strongly that these particles had liquid phase in the atmosphere.

\subsection{Aerosol constituents and mixing states during the JASE traverse}

Figure 7 presents examples of EDX spectra of each aerosol particle collected during the JASE traverse. Although strong peaks of $\mathrm{C}, \mathrm{O}$, and $\mathrm{Ni}$ were detected in all samples, these peaks were derived from the sample substrate. Therefore, $\mathrm{C}, \mathrm{O}$, and $\mathrm{Ni}$ were excluded from discussion in this study. As portrayed in Fig. 7a, strong peaks of $\mathrm{S}$ were observed from aerosol particles with a satellite structure. Comparison among the elemental compositions, morphology (satellite structure), and previous investigations by Yamato et al. (1987) and Hara et al. (2013) showed that these particles might consist mainly of $\mathrm{H}_{2} \mathrm{SO}_{4}$ and $\mathrm{CH}_{3} \mathrm{SO}_{3} \mathrm{H}$, which are derived mainly from oceanic bio-activity. Because EDX can provide only elemental information, we cannot distinguish $\mathrm{SO}_{4}^{2-}$ from $\mathrm{CH}_{3} \mathrm{SO}_{3}^{-}$. Hereinafter, we designate these aerosol particles as "sulfate particles".

In fact, $\mathrm{S}$ and $\mathrm{K}$ were detected from aerosol particles as shown in Fig. 7b. Aerosol particles containing S and $\mathrm{K}$ had no satellite structure. Similar aerosol particles were identified in aerosol samples taken in the lower free troposphere - upper free troposphere in Antarctic region (Hara et al., 2010a, 2010b, 2013).

Peaks of $\mathrm{Mg}$ and $\mathrm{S}$ were obtained from aerosol particles as portrayed in Fig. 7c. Atomic ratios of $\mathrm{Mg}$ and $\mathrm{S}$ of the aerosol particles containing only $\mathrm{Mg}$ and $\mathrm{S}$ were compatible 


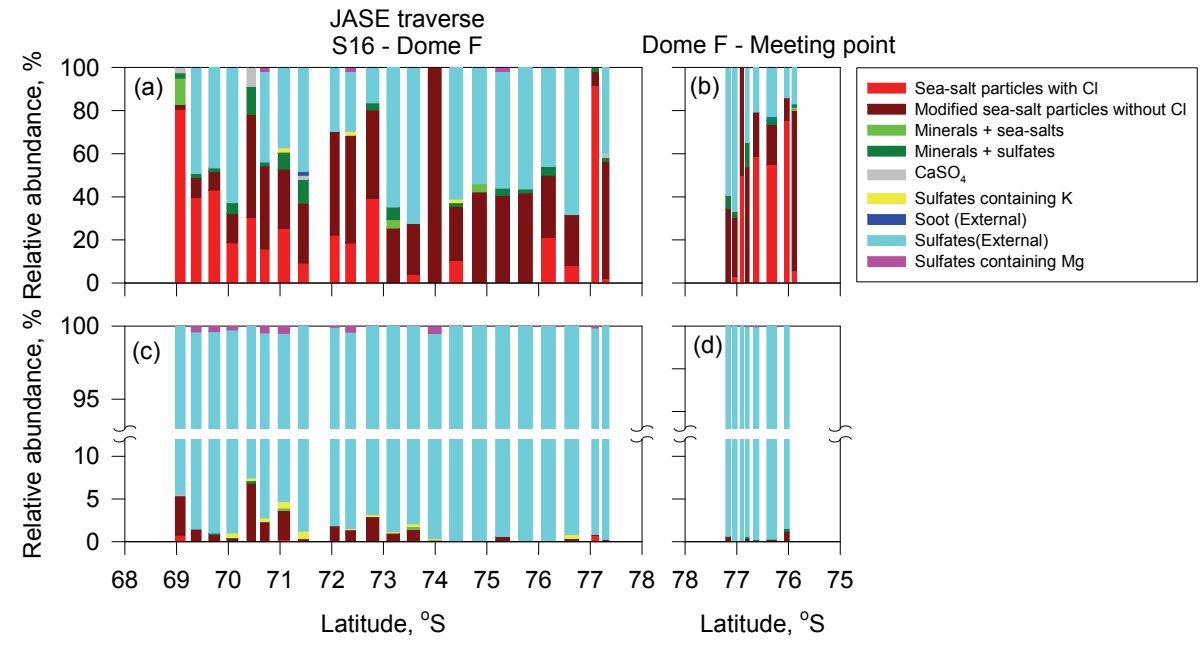

Figure 8. Horizontal features of relative abundance of each aerosol constituent in (a-b) coarse and (c-d) fine modes during the incoming traverse.

with the ratios of $\mathrm{MgSO}_{4}$. Mg-rich sulfate particles in the lower troposphere over Syowa Station were identified dominantly in air masses transported from the Antarctic continent (Hara et al., 2013). Hara et al. (2013) reported that Mg-rich sulfate particles in the Antarctic atmosphere were associated with sea-salt fractionation and sea-salt modification. Details of Mg-rich sulfate particles and sea-salt fractionation are discussed in Sect. 3.7.

Aerosol particles containing $\mathrm{Ca}$ and $\mathrm{S}$ were also observed in this study (Fig. 7d). Because of the atomic ratios of $\mathrm{Ca}$ and $\mathrm{S}$, particles of this type might be $\mathrm{CaSO}_{4}$ particles. $\mathrm{CaSO}_{4}$ particles were identified in the lower troposphere on the Antarctic region (Hara et al., 2010a, 2013). Actually, $\mathrm{CaSO}_{4}$ is well known as a major mineral constituent (gypsum). Moreover, Marion and Farren (1999) and Geilfus et al. (2013) pointed out $\mathrm{CaSO}_{4}$ (gypsum) formation by seasalt fractionation on sea ice in polar regions. However, the origins of $\mathrm{CaSO}_{4}$ particles in the Antarctic atmosphere remain unclear.

Peaks of $\mathrm{Na}, \mathrm{Mg}, \mathrm{S}$, and $\mathrm{Cl}$ were obtained in aerosol particles as shown in Fig. 7e. These elements are major seawater constituents. When artificial $\mathrm{NaCl}$ particles were analyzed using SEM-EDX, the peak height of $\mathrm{Cl}$ was slightly higher than that of Na. Consequently, the particle in Fig. 7e might be identified as partly Cl-depleted sea-salt particles. In addition, $\mathrm{Na}, \mathrm{Mg}$, and $\mathrm{S}$ were detected from the aerosol particle in Fig. 7f. Compared to the aerosol particle in Fig. 7e, the peak height of $\mathrm{S}$ relative to $\mathrm{Na}$ was higher in the particle in Fig. 7f. Additionally, the height of $\mathrm{Mg}$ relative to $\mathrm{Na}$ was higher than that of sea-salt particles depicted in Fig. 7d. The particle in Fig. $7 \mathrm{f}$ might be identified as a wholly Cl-depleted sea-salt particle with slight $\mathrm{Mg}$-enrichment. Although $\mathrm{Na}$, $\mathrm{Mg}$, and $\mathrm{S}$ were detected from the aerosol particle in Fig. $7 \mathrm{~g}$, the peak height of $\mathrm{S}$ was lower than the particles in Fig. 7ef. In addition, the particle in Fig. $7 \mathrm{~g}$ might be identified as a wholly Cl-depleted sea-salt particle. Hereinafter, we designate wholly Cl-depleted particles as "modified sea-salt particles". Less Cl-depleted sea-salt particles and partially $\mathrm{Cl}$ depleted sea-salt particles were divided into "sea-salt particles" in this study. Modification of sea-salt particles is discussed in Sect. 3.6. Although $\mathrm{Mg}$ is a major sea-salt constituent, $\mathrm{Mg}$ was not detected from aerosol particles containing $\mathrm{Na}, \mathrm{K}$, and $\mathrm{Cl}$, as portrayed in Fig. 7h. A particularly strong $\mathrm{K}$ peak relative to Na peak was identified clearly from the particle in Fig. 7h. Na is a dominant constituent in seasalt particles. Therefore, particles of this type were identified as "sea-salt-like particles" in this study. The sea-salt-like particles were observed only at sampling sites on the way from Dome $\mathrm{F}$ to the meeting point in the incoming traverse on 21-23 December 2007 when aerosol particles were collected under conditions with drifting snow.

In fact, $\mathrm{Si}, \mathrm{Al}$, and $\mathrm{S}$ were detected from solid particles as shown in Fig. 7i. Results show that $\mathrm{Al}$ and $\mathrm{Si}$ were major constituents. Therefore, particles of this type might be identified as mineral particles. Here, aerosol particles containing $\mathrm{Si}$ and $\mathrm{Al}$ were classified into "mineral particles". Furthermore, stain and satellite structures were observed around irregular solid core in some mineral particles. Considering that $\mathrm{S}$ was detected in mineral particles (irregular solid particles) satellite structure, these particles were likely to be mineral particle coated by acidic sulfates and $\mathrm{H}_{2} \mathrm{SO}_{4}$. In addition, internal mixtures of minerals and sea-salt particles were often identified in this study (Fig. 7j).

\subsection{Horizontal distributions of aerosol constituents during the JASE traverse}

To compare quantitatively horizontal distributions of each aerosol constituent and mixing states, we estimated the relative abundance (number fraction) of each type of aerosol 

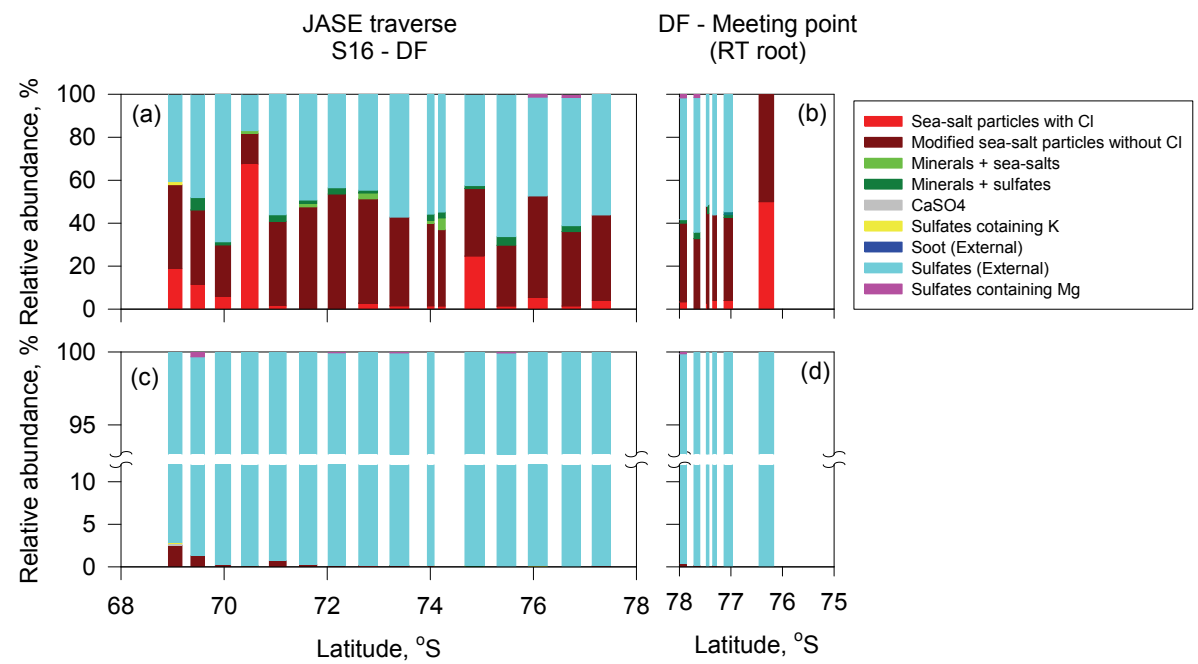

Figure 9. Horizontal features of relative abundance of each aerosol constituent in (a-b) coarse and (c-d) fine modes during the outgoing traverse.

constituent. Considering the mean analyzed particles in each sample in this study, the detection limit of relative abundance was ca. $0.1 \%$ in fine mode and $1-2 \%$ in coarse mode except for samples with lower aerosol density on the substrate in coarse mode. Figures 8 and 9 show horizontal distributions of relative abundance of aerosol mixing states in coarse and fine modes during the incoming traverse (14 November27 December 2007) and the outgoing traverse (27 December 2007-24 January 2008).

\subsubsection{Sea-salts}

In coarse mode, major aerosol particles were sea-salt particles, modified sea-salt particles and sulfate particles. The relative abundance of sea-salt particles in coarse mode was larger than $40 \%$ near the coast in the incoming traverse. Relative abundance of sea-salt particles in coarse mode decreased gradually in inland areas, with exception of the high abundance at sampling sites in $77-76^{\circ} \mathrm{S}$ on the way from Dome F Station to the meeting point in the incoming traverse (Fig. 8d). As described above, sea-salt-like particles $(\mathrm{Na}-\mathrm{K}-\mathrm{Cl})$ were observed predominantly in coarse mode at these sites. With the gradual decrease of the relative abundance of sea-salt particles, the relative abundance of the modified sea-salt particles increased gradually up to $40 \%$ on the Antarctic plateau. By contrast, the modified sea-salt particles were dominant in fine mode in the incoming traverse. Because of the predominance of sulfate particles in fine mode, the relative abundance of sea-salt particles and the modified sea-salt particles was less than $6.8 \%$ even at latitudes lower than $72^{\circ} \mathrm{S}$ and less than $2.8 \%$ at latitudes higher than $72^{\circ} \mathrm{S}$ during the incoming traverse. According to the 5-day backward trajectory as depicted in Fig. 3, transport from the coasts was found only at $69-71^{\circ} \mathrm{S}$ during the incoming traverse, whereas air masses in the inland area $\left(>72^{\circ} \mathrm{S}\right)$ were transported over the continent during the 5 days prior. Therefore, isolation from the coastal regions might cause gradual distributions of sea-salt particles and modified sea-salt particles in the continent. The transport pathway, however, cannot account for the high relative abundance of sea-salt particles and the modified sea-salt particles, for example at $72-73^{\circ} \mathrm{S}$ and at $77-76^{\circ} \mathrm{S}$. As depicted in Fig. 4, the aerosol number concentrations increased considerably, particularly in coarse mode, under strong wind conditions in the incoming traverse to the meeting point. Consequently, high aerosol number concentrations and their high relative abundance might result from redistribution of aerosol particles such as sea-salt particles from the snow surface. Therefore, the horizontal distribution of relative abundance of sea-salt particles and the modified sea-salt particles on the Antarctic continent during summer might be associated with the transport pathway and release from the snow surface via wind-blowing.

Relative abundance of sea-salt particles and the modified sea-salt particles in coarse mode ranged mostly lower than $60 \%$ during the outgoing traverse. Although the total relative abundance of sea-salt particles and the modified sea-salt particles in coarse mode was similar to that in the incoming traverse except for the high relative abundance under strong wind conditions, the modified sea-salt particles were dominant in the outgoing traverse. However, the relative abundance of sea-salt particles and the modified sea-salt particles in fine mode was mostly less than $0.5 \%$ in inland areas during the outgoing traverse. In some samples taken on the Antarctic plateau, sea-salt particles and the modified sea-salt particles were not detected in fine mode. Compared to the horizontal distributions of sea-salt particles and the modified sea-salt particles in fine mode during the incoming traverse, relative abundances of sea-salt particles and the modified seasalt particles were remarkably lower. Mass concentrations 
of sea salts $\left(\mathrm{Na}^{+}\right)$in aerosol particles show a minimum at Syowa and Dome F stations during summer (Hara et al., 2004). In addition, the relative abundance of sea-salt particles and the modified sea-salt particles decreased considerably over Syowa Station (Hara et al., 2013). Although blizzard attributable to approaching cyclone occurs until early December at Syowa Station, few blizzards occur usually in the midDecember-January period (Sato and Hirasawa, 2007). The seasonal feature of approaching cyclone are closely related to the origins of air masses over the Antarctic continent, as suggested by Suzuki et al. (2013). Therefore, the difference of the relative abundance between in the incoming traverse and in the outgoing traverse might correspond to seasonal features of sea-salt particles, air mass origins, and transport pathway from the end of spring to summer on the Antarctic continent.

\subsubsection{Sulfates}

As classified in Sect. 3.4, the following aerosol particles containing sulfates were identified in this study: (1) sulfate particles, (2) modified sea-salt particles, (3) sulfate particles containing $\mathrm{K}$, (4) $\mathrm{MgSO}_{4}$ particles, (5) $\mathrm{CaSO}_{4}$ particles, and (6) mineral particles internally mixed with sulfates. Because horizontal distributions of the modified sea-salt particles and mineral particles internally mixed with sulfates were described in Sects. 3.5.1 and 3.5.3, respectively, their description is excluded from this section.

Figures 8 and 9 show that sulfate particles were the major aerosol particles in coarse mode and that they were dominant in fine modes. Particularly, the mean relative abundance of sulfate particles in fine mode was $98.5 \%$ in the incoming traverse and $99.5 \%$ in the outgoing traverse. In some samples taken on the Antarctic plateau, the relative abundance of sulfate particles in fine mode reached $100 \%$ in incoming and outgoing traverses. Considering detection limits of the relative abundance in fine mode, the upper limit of relative abundance of aerosol particles other than sulfate particles might be less than $0.1 \%$ in these samples $(100 \%$ abundance of sulfate particles). Higher relative abundance of sulfate particles in the outgoing traverse is likely to result from (1) increase of the number concentrations of sulfate particles in fine mode by particle growth of ultra-fine sulfate particles by hygroscopicity, (2) cloud processes, and (3) decrease of the number concentration of sea-salt particles and the modified sea-salt particles during the summer. Indeed, mass concentrations of nss- $\mathrm{SO}_{4}^{2-}$ and sea-salts $\left(\mathrm{Na}^{+}\right)$, respectively showed a maximum and minimum in the summer (January-February) along the Antarctic coast and inland (e.g., Minikin et al., 1998; Hara et al., 2004; Weller and Wagenbach, 2007; Preunkert et al., 2008; Udisti et al., 2012). The relative abundance of sulfate particles in fine mode was $82.9-98.2 \%$ (mean, 93.1\%) in the boundary layer and 96.2-99.7\% (mean, 98.1\%) in the lower free troposphere over Syowa Station, Antarctica during mid-November through January (Hara et al., 2013). Con- sequently, the relative abundance of sulfate particles in fine mode near the surface on the Antarctic continent was similar to that in the lower free troposphere over the Antarctic coast (Syowa Station). The relative abundance of sulfate particles in coarse mode often exceeded $40 \%$ on the Antarctic continent during the JASE traverse. Such a high relative abundance of coarse sulfate particles was not observed in the boundary layer but often in the lower free troposphere over Syowa Station (Hara et al., 2013). As described above, "sulfate particles" in this study did not contain $\mathrm{Na}$, $\mathrm{Al}$, and Si. Therefore, these particles might be composed of $\mathrm{SO}_{4}^{2-}$ and $\mathrm{CH}_{3} \mathrm{SO}_{3}^{-}$as suggested by Hara et al. (2005). In addition, chemical tests using the $\mathrm{Ca}$ thin-film method implied that aerosol particles containing $\mathrm{SO}_{4}^{2-}$ were present as acidic states (i.e., sulfuric acid particles) (Yamato et al., 1987a, b). Consequently, sulfate particles might be grown to coarse mode through (1) hygroscopic growth, (2) cloud processes, (3) heterogeneous sulfate formation and (4) coagulation and condensation of condensable vapours (e.g., $\mathrm{H}_{2} \mathrm{SO}_{4}$ gas) under conditions with low number concentrations of pre-existing particles on the Antarctic continent.

The relative abundance of K-rich sulfate particles ranged from not detected (n.d.) to $2.0 \%$ in coarse mode and ranged from n.d. to $0.9 \%$ in fine mode in this study. Although K-rich sulfate particles were obtained in a few samples in coarse mode, these particles were observed often in fine mode in this study. Moreover, K-rich sulfate particles were often observed in the incoming traverse. In addition, the relative abundance of K-rich sulfate particles in the incoming traverse was higher than that in the outgoing traverse. K-rich sulfate particles were also distributed in the boundary layer to the upper free troposphere over Syowa Station (Hara et al., 2010b, 2013). Actually, K-rich sulfate particles cannot be formed through gas-to-particle conversion from aerosol precursors derived from oceanic bioactivity. Therefore, Krich sulfate particles might be non-biogenic aerosol particles. As discussed by Okada et al. (2001, 2008) and Niemi et al. (2005), K-rich sulfate particles and nss-K in aerosol particles are released from combustion processes such as biomass burning.

As discussed above and by Hara et al. (2013), K-rich sulfate particles might have originated from biomass burning and fossil fuel combustion. As shown in Fig. 3, direct transport from outsides of the Antarctic Circle was not found for the 5 days prior. Moreover, the source strength of combustion of fossil fuel is extremely low in Antarctic regions. Particularly, biomass burning does not occur in the Antarctic regions. Therefore, sulfate particles containing $\mathrm{K}$ were likely to have been transported to the Antarctic continent via the free troposphere during summer for the 5 days prior. The presence of combustion-origin aerosol particles (e.g., sulfate particles containing K) was supported by high BC concentrations at the South Pole in the summer (Bodhaine, 1995). This difference of relative abundance in incoming and outgoing traverses might be attributed to seasonal features of K-rich 
sulfate particles, air mass origins, and transport pathway in the inland area during late spring-summer.

The relative abundance of Mg-rich sulfate particles (probably $\mathrm{MgSO}_{4}$ ) examined in this study ranged from n.d. to $1.8 \%$ in coarse mode and ranged from n.d. to $0.5 \%$ in fine mode. During the incoming traverse, Mg-rich sulfate particles were found frequently in fine mode at sampling sites in $69.2-72.5^{\circ} \mathrm{S}$, although those were observed in some aerosol samples collected at plateau sites. However, Mg-rich sulfate particles were identified mainly on the Antarctic plateau during the outgoing traverse. The relative abundance of Mg-rich sulfate particles was lower in the outgoing traverse than that in the incoming traverse. Mg-rich sulfate particles were distributed mostly in fine mode over Syowa Station (Hara et al., 2013). An earlier investigation (Hara et al., 2013) showed that Mg-rich sulfate particles were associated with sea-salt fractionation (Mg separation) and modification ( $\mathrm{Cl}$ loss by heterogeneous reactions). Consequently, the presence of $\mathrm{Mg}$ rich sulfate particles in the atmosphere near the surface on the Antarctic continent in this study strongly suggests that sea-salt fractionation occurs on the Antarctic continent during summer. Details of sea-salt fractionation are discussed in Sect. 3.7.

Relative abundance of Ca-rich sulfate particles (probably $\mathrm{CaSO}_{4}$ ) ranged from n.d. to $8.7 \%$ in coarse mode and ranged from n.d. to $0.2 \%$ in fine mode in the incoming traverse. However, the relative abundance of Ca-rich sulfate particles in the outgoing traverse was n.d. in coarse mode and ranged from n.d. to $0.1 \%$ in fine mode. Although Ca-rich sulfate particles were not detected in most samples in either traverses, Ca-rich sulfate particles were identified mainly near coasts $\left(<72^{\circ} \mathrm{S}\right)$. Although Ca-rich sulfates such as gypsum are mineral components, most Ca-rich sulfates were not mixed with $\mathrm{Al}$ and $\mathrm{Si}$, which are major elements of mineral particles. Consequently, horizontal distributions and external mixing states of Ca-rich sulfates imply the important contribution of non-mineral origins such as sea-salt fractionation on sea ice as reported by Geilfus et al. (2013).

\subsubsection{Minerals}

The relative abundance of mineral particles ranged in n.d.$14.6 \%$ in coarse mode and n.d. $-0.4 \%$ in fine mode during the incoming traverse, although the relative abundance ranged in n.d. $-5.7 \%$ in coarse mode and n.d. $-0.1 \%$ in fine mode during the outgoing traverse. Mean relative abundance in coarse mode was 3.8 and $1.8 \%$ in incoming and outgoing traverses, respectively, and that in fine mode was 0.1 and $0.01 \%$ in incoming and outgoing traverses. Most mineral particles were internally mixed with sea-salts or sulfates in this study. Although the mineral particles were observed mainly in coarse mode, SEM-EDX analysis showed that the size of irregular solid cores containing $\mathrm{Al}$ and $\mathrm{Si}$ was of submicrometre in this study. The size of irregular solid cores was coincident with the size distribution of water-insoluble parti- cles (mainly mineral particles) in ice cores taken in Antarctica (e.g., Ram et al., 1988; Delmonte et al., 2004, 2007). In contrast, external mixing states of mineral particles were often present in the boundary layer and free troposphere over Syowa Station located at the coast (Hara et al., 2006, 2013). The difference of mixing states of mineral particles suggests that they changed gradually to internal mixtures through coagulation in cloud processes, and through heterogeneous reactions during their transport to inland areas. As described above, a change of mixing state of mineral particles can engender particle sizes greater than the external mixing states of mineral particles. Because of the higher dry deposition velocity of coarse aerosol particles, internal mixing among minerals, sulfate, and sea-salts during transport might enhance the efficient deposition of minerals onto the snow surface on the Antarctic continent.

\subsection{Sea-salt modification during the JASE traverse}

\subsubsection{Sea-salt modification in coarse and fine modes}

Figure 10 portrays examples of ternary plots $(\mathrm{Na}-\mathrm{S}-\mathrm{Cl})$ of sea-salt particles and the modified sea-salt particles during the JASE traverse. To avoid misunderstanding of sea-salt modification, the internal mixed sea-salt and mineral particles were excluded from the ternary plots and discussion. Red and blue stars respectively denote atomic ratios of bulk seawater ratios and wholly $\mathrm{Cl}$ depleted sea-salt particles by $\mathrm{SO}_{4}^{2-}$. The black line represents the stoichiometric line from the sea salt particles with bulk seawater ratio (red star) to the $\mathrm{Cl}$-depleted sea salt particles by sulfates (blue star). When $\mathrm{Cl}$ in sea-salt particles is replaced stoichiometrically to $\mathrm{SO}_{4}^{2-}$ by heterogeneous reactions, each sea salt particle is distributed along the stoichiometric line.

Most sea-salt particles in coarse mode had $\mathrm{Cl}$ ratios lower than the seawater ratio in this study. Although $\mathrm{S}$ ratios increased gradually with decreased $\mathrm{Cl}$ ratios in sea-salt particles, the $\mathrm{S}$ ratios in sea-salt particles were less than those of the stoichiometric line on the Antarctic continent during summer, which suggests that sea-salt particles were modified not only with $\mathrm{SO}_{4}^{2-}$ but also with acidic species other than acidic sulfur species such as $\mathrm{SO}_{4}^{2-}$. Plausible acidic species other than $\mathrm{SO}_{4}^{2-}$ and $\mathrm{CH}_{3} \mathrm{SO}_{3}^{-}$for $\mathrm{Cl}$ loss from seasalt particles are reactive nitrogen oxides such as $\mathrm{HNO}_{3}$, $\mathrm{N}_{2} \mathrm{O}_{5}$, and $\mathrm{NO}_{3}$ (e.g., Hara et al., 1999) and organic acids (Kerminen et al., 2000; Laskin et al., 2012). Previous studies of aerosol chemistry in Antarctic regions showed that $\mathrm{NO}_{3}^{-}$concentrations were higher than those of organic acids (oxalate, formate, and acetate) (Jourdain and Legrand, 2002; Weller et al., 2002, 2007; Rankin and Wolff, 2003; Legrand et al., 2004; Hara et al., 2010a; Weller et al., 2011). Furthermore, higher concentrations of reactive nitrogen oxides (e.g., $\mathrm{HNO}_{3}$ and NO) were observed on the Antarctic continent and coasts during summer (Davis et al., 2004; Dibb et al., 2004; Jones et al., 2011). Details of origins of the reactive nitrogen 


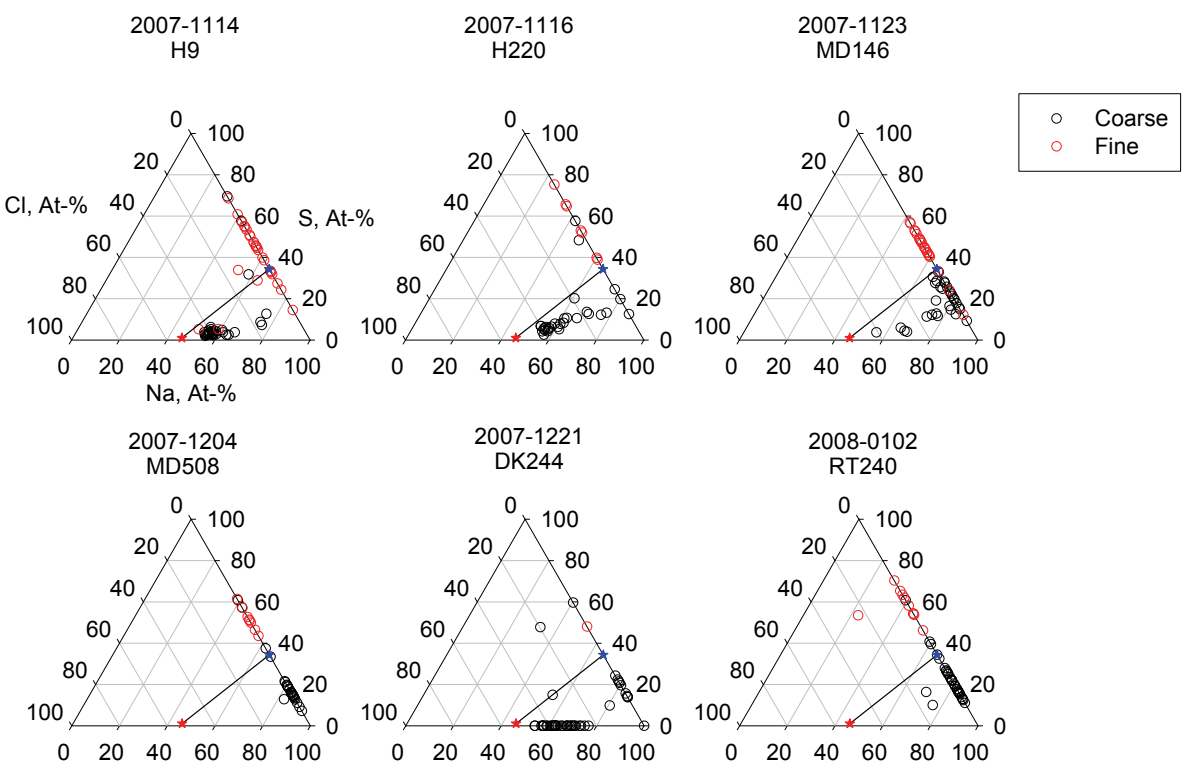

Figure 10. Ternary plots (Na-S-Cl) of sea-salt particles in coarse and fine modes during the JASE traverse. Red, and blue stars respectively denote atomic ratios of (1) bulk seawater, and (2) wholly $\mathrm{Cl}$ depleted sea-salt particles with sulfates. Black lines represent stoichiometric lines among constituents.

oxides are discussed in the next section. Therefore, heterogeneous $\mathrm{NO}_{3}^{-}$formation on sea-salt particles might make an important contribution to sea-salt modification in inland areas during summer. In contrast to sea-salt modification in coarse mode, most of the modified sea-salt particles in fine mode were distributed in the $\mathrm{Cl}$ ratio of ca. $0 \%$ and higher $\mathrm{S}$ atomic ratio relative to the modified sea-salt particles. Therefore, fine sea-salt particles on the Antarctic continent might be modified preferentially with acidic sulfur species such as $\mathrm{SO}_{4}^{2-}$ and $\mathrm{CH}_{3} \mathrm{SO}_{3}^{-}$.

\subsubsection{Horizontal features of sea-salt modification on the Antarctic continent}

Figures 11 and 12 respectively portray horizontal features of the atomic ratios of $\mathrm{Cl} / \mathrm{Na}$ and $\mathrm{S} / \mathrm{Na}$ of sea-salt particles and the modified sea-salt particles in coarse and fine modes during the incoming and outgoing traverses. The internal mixing particles between sea salts and minerals were excluded from the box plots. A latitudinal gradient of $\mathrm{Cl} / \mathrm{Na}$ ratios in coarse mode was observed in $69-71^{\circ} \mathrm{S}$ in the incoming traverse. High $\mathrm{Cl}$ depletion was identified in most aerosol samples obtained for the Antarctic plateau, except for some samples taken at $76.5-76^{\circ} \mathrm{S}$ in the incoming traverse from Dome $\mathrm{F}$ to the meeting point. In spite of the latitudinal gradient of $\mathrm{Cl} / \mathrm{Na}$ ratios in coarse mode in $69-71^{\circ} \mathrm{S}$ in the incoming traverse, the $\mathrm{S} / \mathrm{Na}$ ratio increased slightly. Similarly, median $\mathrm{S} / \mathrm{Na}$ ratios of sea-salt particles and the modified seasalt particles in coarse mode were distributed approximately around 0.2 during the JASE traverse. When sea-salt particles are modified solely with $\mathrm{SO}_{4}^{2-}$, the $\mathrm{S} / \mathrm{Na}$ ratios in sea-salt particles are 0.5. As suggested in ternary plots in Fig. 10, therefore, $\mathrm{NO}_{3}^{-}$contributed dominantly to sea-salt modification in coarse mode on the Antarctic continent.

Hara et al. $(2005,2013)$ reported that most sea-salt particles in coarse mode were modified slightly over Syowa station in the summer. Some were modified with $\mathrm{SO}_{4}^{2-}$. Consequently, the acids contributing to sea-salt modification differed between those in coarse sea-salt particles on the Antarctic coasts and those on the continent during summer. The air mass history and origins of coarse sea-salt particles, $\mathrm{NO}_{3}^{-}$, and its precursors on the Antarctic continent must be discussed to elucidate the strong contribution of $\mathrm{NO}_{3}^{-}$to sea-salt modification. The 5-day backward trajectory, as depicted in Fig. 3, shows that continental air masses on the Antarctic plateau had not been transported directly from the coasts during the 5 days prior. Because of efficient dry deposition of coarse aerosol particles, coarse particles suspended at the Antarctic coasts might be transported only slightly to the Antarctic continent (particularly the Antarctic plateau) for longer than 5 days. As discussed in Sects. 3.2 and 3.5.1, most coarse sea-salt particles on the Antarctic plateau were likely to have originated from surface snow on the Antarctic continent. Figures 11 and 12 show that high $\mathrm{Cl} / \mathrm{Na}$ ratios on the Antarctic plateau often corresponded to conditions with strong winds and drifting snow. Consequently, seasalt particles might have high $\mathrm{Cl} / \mathrm{Na}$ ratios immediately after release from the snow surface. Then, sea-salt particles in coarse mode might be modified gradually with reactive nitrogen oxides such as $\mathrm{HNO}_{3}$ in the continental atmosphere during transport over the Antarctic continent. 


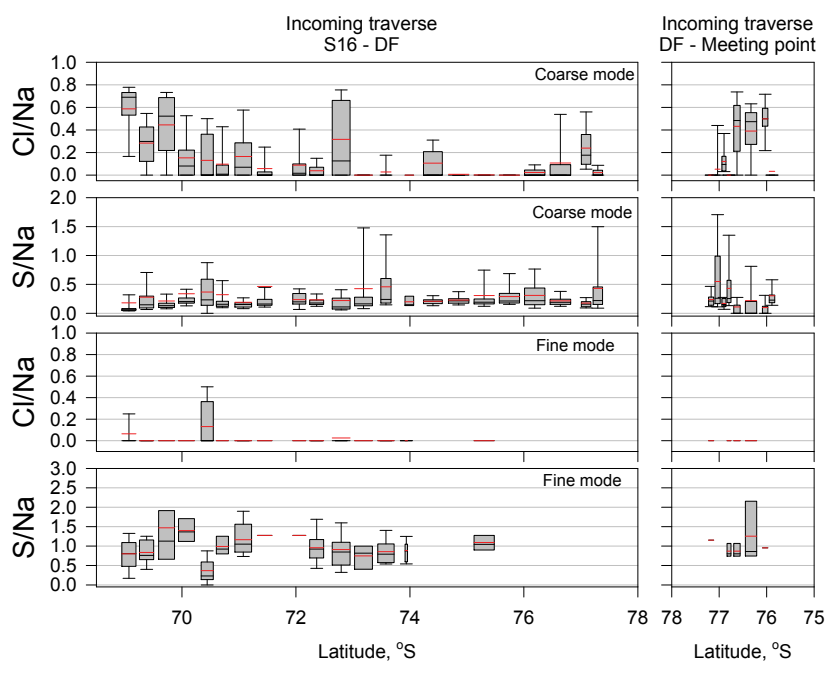

Figure 11. Horizontal features of atomic ratio of $\mathrm{Cl} / \mathrm{Na}$ and $\mathrm{S} / \mathrm{Na}$ in coarse and fine modes during the incoming traverse. In box plots, the top bar, top box line, black middle box line, bottom box line, and bottom bar respectively denote values of 90, 75, 50 (median), 25 , and $10 \%$. The red line shows mean values.

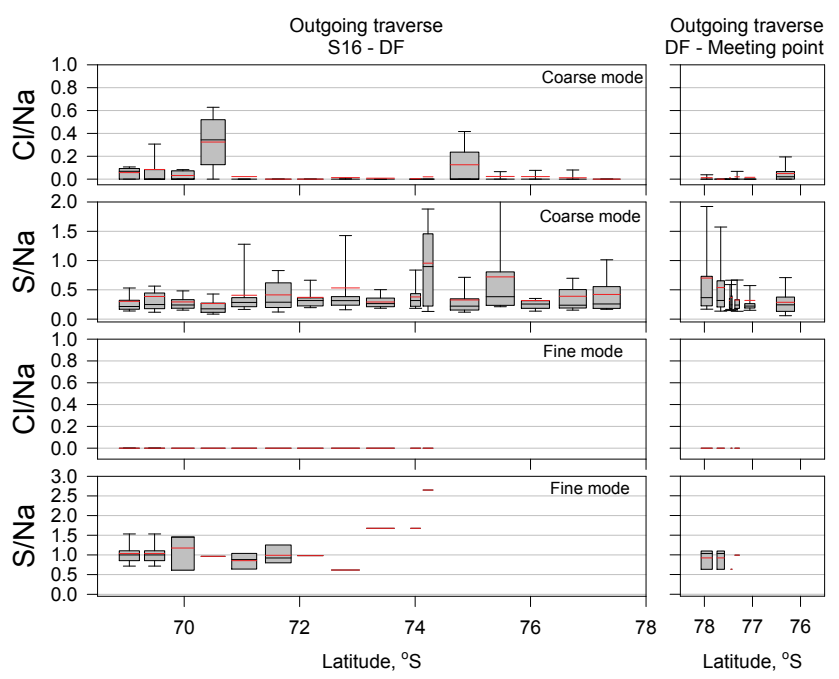

Figure 12. Horizontal features of atomic ratio of $\mathrm{Cl} / \mathrm{Na}$ and $\mathrm{S} / \mathrm{Na}$ in coarse and fine modes during the outgoing traverse. In box plots, the top bar, top box line, black middle box line, bottom box line, and bottom bar respectively denote values of 90, 75, 50 (median), 25 , and $10 \%$. The red line shows mean values.

Field measurements of the surface snow in polar regions (e.g., Davis et al., 2001, 2004; Frey et al., 2009; Jones et al., 2011) implied photochemical-recycling mechanisms of snow-nitrate near the surface of polar regions during summer. Indeed, high NO concentrations (order of several hundred pptv) were observed at the South Pole Station during summer (Davis et al., 2001; Huey et al., 2004; Helmig et al., 2008; Neff et al., 2008). Actually, $\mathrm{NO}_{\mathrm{x}}$ can be converted to $\mathrm{HNO}_{3}$ in the atmosphere. Therefore, the high $\mathrm{NO}_{\mathrm{x}}$ concen- tration during summer on the Antarctic plateau might engender efficient $\mathrm{HNO}_{3}$ production near the surface, as suggested by Dibb et al. (2004) and Huey et al. (2004). Considering the high $\mathrm{NO}_{3}^{-}$concentration in the surface snow around Queen Maud Land, especially around Dome F Station (Bertler et al., 2005), considerable $\mathrm{HNO}_{3}$ production in the atmosphere might occur on the Antarctic plateau. Therefore, sea-salt modification in coarse mode through heterogeneous reactions with reactive nitrogen oxides (mainly $\mathrm{HNO}_{3}$ ) might occur preferentially on the Antarctic continent during summer.

By contrast, $\mathrm{S} / \mathrm{Na}$ ratios in fine sea-salt particles exceeded mostly 0.5 during the traverse. The high $\mathrm{S} / \mathrm{Na}$ ratios in each sea-salt particle in fine mode imply that sulfates were formed on the fine sea-salt particles through heterogeneous reactions with gaseous sulfur species such as $\mathrm{H}_{2} \mathrm{SO}_{4}$ and $\mathrm{SO}_{2}$. High $\mathrm{S} / \mathrm{Na}$ ratios in the modified sea-salt particles were also obtained in the boundary layer and lower free troposphere over Syowa Station during summer (Hara et al., 2013). Because of the longer residence time of fine aerosol particles, the modified sea-salt particles in fine mode with high $\mathrm{S} / \mathrm{Na}$ ratio might be supplied by transport from coastal regions to the continent and might be formed through heterogeneous processes during transport.

\subsection{Sea-salt fractionations on the Antarctic continent during summer}

\subsubsection{Sea-salt fractionations in coarse and fine mode}

Figure 13 shows examples of ternary plots of sea-salts (Na, $\mathrm{Mg}$, and S) and Mg-rich sulfates in coarse and fine modes. Internal mixtures of sea salts and minerals were removed from the ternary plots. In the ternary plots, sea-salt particles with bulk seawater ratio are distributed around the red star (bulk seawater ratio). When the sea-salt particles are modified by sulfate and are not fractionated, they are distributed around the stoichiometric line between the red star (seawater ratio) and the blue star (modified sea-salt ratio with sulfate). With sea-salt fractionation by precipitation of $\mathrm{Na}$ salts such as mirabilite $\left(\mathrm{Na}_{2} \mathrm{SO}_{4} 10 \mathrm{H}_{2} \mathrm{O}\right)$ and hydrohalite $\left(\mathrm{NaCl} 2 \mathrm{H}_{2} \mathrm{O}\right)$ (Hara et al., 2012), $\mathrm{Mg}$ in sea-salt particles can be enriched gradually. For cases in which sea-salt fractionation (replacement between $\mathrm{Na}$ and $\mathrm{Mg}$ ) occurs without sea-salt modification by sulfate, sea-salt particles are distributed around the stoichiometric line between the red star (bulk seawater ratio) and the cyan star $\left(\mathrm{MgCl}_{2}\right)$. When sea-salt fractionation and sea-salt modification by sulfate occur stoichiometrically and simultaneously, sea-salt particles are distributed around the stoichiometric line between the red star (seawater ratio) and the green star $\left(\mathrm{MgSO}_{4}\right)$.

Because sea-salt particles were modified dominantly during JASE (as shown in Figs. 10-12), most sea-salt particles and the modified sea-salt particles in coarse mode were distributed in $60-90 \%$ of the $\mathrm{Na}$ atomic ratio. The $\mathrm{Mg}$ ratios in coarse mode, however, were greater than the stoichiometric 


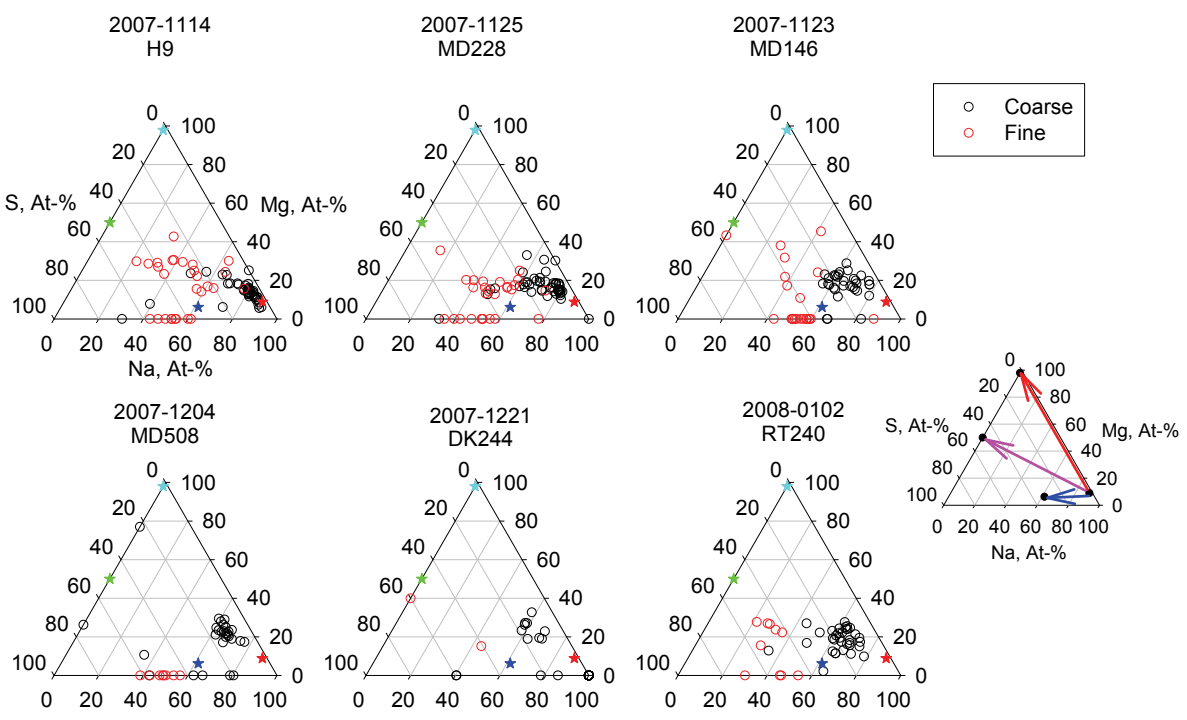

Figure 13. Ternary plots (Na-Mg-S) of sea-salt particles in coarse and fine modes during the JASE traverse. Red, blue, cyan, and green stars respectively denote atomic ratios of (1) bulk seawater, (2) wholly Cl depleted sea-salt particles with sulfates, (3) $\mathrm{MgCl}_{2}$, and (4) $\mathrm{MgSO}_{4}$. Blue, pink, and red lines represent stoichiometric lines among constituents.

line of sea-salt modification (between the red star and blue star). Some of the modified sea-salt particles had Mg ratio $\approx 0$, even in coarse mode. The $\mathrm{Mg}$ ratios in fine mode were distributed at $\mathrm{Mg}$ ratio $\approx 0$ and around the stoichiometric line between the red star (seawater) and green star $\left(\mathrm{MgSO}_{4}\right)$. Here, we designate sea-salt particles with $\mathrm{Mg}$ ratio $\approx 0$ as "Mg-free sea-salt particles". In addition to $\mathrm{Mg}$ free sea-salts, $\mathrm{MgSO}_{4}$ particles were often observed in this study, as shown in Figs. 7-9 and 13. Similar distributions were observed in sea-salt particles and the modified sea-salt particles collected over Syowa Station (Hara et al., 2013). $\mathrm{The} \mathrm{Mg} / \mathrm{Na}$ ratios cannot be changed by sea-salt modification. Sea-salt fractionation in sea ice regions during winter through spring (e.g., precipitation of mirabilite and hydrohalite) can promote $\mathrm{Mg}$ enrichment in sea-salt particles, as reported by Hara et al. (2012). Consequently, sea-salt fractionation in sea ice regions cannot account for the presence of $\mathrm{Mg}$-Free sea-salt particles during spring-summer. Because Mg-rich sulfate particles over Syowa Station were identified in the air masses from the Antarctic continent (Hara et al., 2013), discussion must address horizontal features of $\mathrm{Mg}$ rich sulfates, $\mathrm{Mg}$-rich sea-salt particles and $\mathrm{Mg}$-free sea-salt particles on the Antarctic regions. Then it will be possible to assess the possibility of sea-salt fractionation on the Antarctic continent.

\subsubsection{Horizontal features of sea-salt fractionation on the Antarctic continent}

To elucidate sea-salt fractionation on the Antarctic continent during summer, we must compare horizontal features of sea-salt constituents on the Antarctic continent. Figure 14 depicts horizontal features of $\mathrm{Mg} / \mathrm{Na}$ ratios in coarse and fine modes during the JASE traverse. Internal mixtures of sea salts and minerals were removed from the plots. $\mathrm{Mg} / \mathrm{Na}$ ratios in fine mode were varied largely in coming traverse. Because of lower relative abundance of sea-salt particles and the modified sea-salt particles in fine mode, horizontal features of $\mathrm{Mg} / \mathrm{Na}$ ratios in fine mode were obtained only in $69-73.5^{\circ} \mathrm{S}$ in the incoming traverse. The large variation of $\mathrm{Mg} / \mathrm{Na}$ ratios might be attributed to presence of Mg-rich sea-salt particles and $\mathrm{Mg}$-free sea-salt particles in fine mode, as shown in the ternary plots (Fig. 13). Median $\mathrm{Mg} / \mathrm{Na}$ ratios in coarse mode were approximately 0.32 in the incoming traverse and 0.31 in the outgoing traverse. Because of $\mathrm{Mg} / \mathrm{Na}$ ratio $\approx 0.11$ in bulk seawater (e.g., Wilson, 1975), $\mathrm{Mg}$ might be enriched in most sea-salt particles in coarse mode. In addition, $\mathrm{Mg}$-free sea-salt particles $(\mathrm{Mg} / \mathrm{Na}$ ratio $\approx 0$ ) in coarse mode were identified often on the Antarctic continent, particularly on the Antarctic plateau. For example, Mg-free sea-salt particles in coarse mode were dominant in three samples taken on 21-23 December 2007 (76.6$76.0^{\circ} \mathrm{S}$ ) in the traverse from Dome $\mathrm{F}$ to the meeting point, as shown in Fig. 14. The presence of Mg-free sea-salt particles in coarse mode corresponded often to occurrence of drifting snow and high aerosol number concentrations in coarse mode in the incoming traverse. $\mathrm{Mg}$-rich sea-salt particles, $\mathrm{Mg}$-free sea-salt particles, and $\mathrm{MgSO}_{4}$ particles were present also in fine mode on the Antarctic continent, although the low relative abundance of sea-salt particles and the modified sea-salt particles prevented us from elucidating the horizontal features of $\mathrm{Mg} / \mathrm{Na}$ ratios on the Antarctic plateau. These horizontal features of $\mathrm{Mg} / \mathrm{Na}$ ratios during the JASE traverse imply strongly that the fractionated sea-salt particles were 


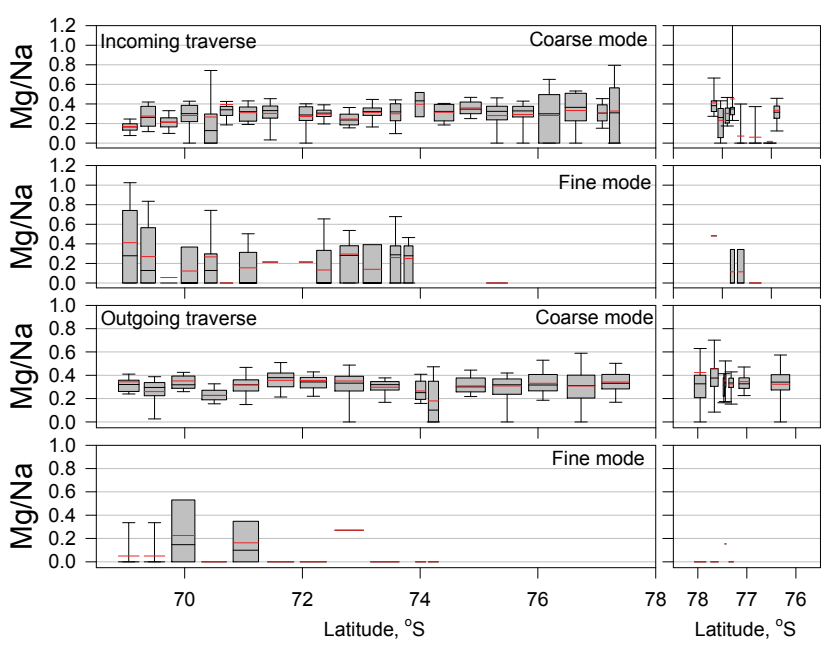

Figure 14. Horizontal features of the atomic ratio of $\mathrm{Mg} / \mathrm{Na}$ in coarse and fine modes during the incoming traverse. In box plots, the top bar, top box line, black middle box line, bottom box line, and bottom bar respectively denote values of 90, 75, 50 (median), 25 , and $10 \%$. The red line shows mean values.

distributed widely throughout the Antarctic continent during summer. Mg-free sea-salt particles were identified mainly in fine mode and rarely in coarse mode over Syowa Station (Hara et al., 2013). Figure 3 shows that air masses on the Antarctic plateau were isolated from coastal regions for the 5 days prior. The lower relative abundance of $\mathrm{Mg}$-free seasalt particles in coarse mode over Syowa Station suggests that Mg-free sea-salt particles and other fractionated sea-salt particles such as Mg-rich sulfates and Mg-rich sea-salts had not originated from coastal regions, considering the efficient dry deposition of aerosol particles in coarse mode. Aerosol particles on the Antarctic plateau, especially in coarse mode, were supplied to a marked degree from snow surface by wind blowing under strong conditions, as described above. Furthermore, $\mathrm{Mg}$-rich sulfates and $\mathrm{Mg}$-free $\mathrm{NaCl}$ were present in surface snow (Iizuka et al., 2012). Therefore, the fractionated sea-salt particles (Mg-rich sea-salt particles, $\mathrm{Mg}$-free sea-salt particles, and $\mathrm{MgSO}_{4}$ particles) might have originated from surface snow on the Antarctic continent. Considering that $\mathrm{Mg}$-free sea-salt particles were often observed under strong wind conditions (especially on 21-23 December), strong winds might be necessary for the release of $\mathrm{Mg}$-free sea-salt particles.

To explain the presence of $\mathrm{Mg}$-rich sea-salt particles, $\mathrm{Mg}$ free sea-salt particles and $\mathrm{MgSO}_{4}$ particles on the snow surface of the Antarctic continent, it is necessary to discuss $\mathrm{Mg}$ separation processes. Redistribution of chemical constituents can occur through (1) seawater freezing (Marion and Farren, 1999; Hara et al., 2012), and (2) phase transformation by deliquescence and efflorescence (e.g., Ge et al., 1998; Wise et al., 2009; Woods et al., 2010). Sea-salt fractionation in seawater freezing depends on the temperature (Marion and
Farren, 1999; Hara et al., 2012). The air temperature on the Antarctic plateau was often below $-30^{\circ} \mathrm{C}$ even during summer, as presented in Fig. 2 and previous investigations (King et al., 2006; Hirasawa et al., 2013). Air temperature might constitute an important condition for some sea-salt precipitation (e.g., ca. -34 and $-36^{\circ} \mathrm{C}$ for $\mathrm{KCl}$ and $\mathrm{MgCl}_{2} 12 \mathrm{H}_{2} \mathrm{O}$ ), as discussed by Marion and Farren (1999). Unlike sea-salts in seawater, however, sea-salts in snow on the Antarctic content were supplied solely by deposition of sea-salt particles that had been transported from coastal regions. When Mg separation is controlled only by lower temperatures, $\mathrm{Mg}$-free seasalt particles, Mg-rich sea-salt particles, and Mg-rich sulfate particles can be present in the Antarctic regions. However, Mg-free sea-salt particles were not observed over Syowa Station during winter in the air masses transported from the continent and coastal regions (Hara et al., 2013). This result implies that Mg separation was controlled not only by lower air temperature but also by other factors.

Figure 2 show that the air temperature near the surface had diurnal change also in continental areas. Furthermore, strong diurnal change of air temperatures and solar radiation engender water sublimation on the snow surface of the Antarctic continent (e.g., Kameda et al., 1997; Motoyama et al., 2005). With strong diurnal change of the air temperature, the relative humidity might exhibit a diurnal change near the snow surface on the Antarctic continent during summer. Actually, relative humidity reached ca. $100 \%$ during the local night-time and reached a minimum in the afternoon at Kohnen Station during summer (Van As et al., 2005). The diurnal variation of the relative humidity can engender (1) phase transformation by deliquescence of available sea-salts on surface snow, (2) condensation and re-freezing of water vapour (e.g., formation of surface hoar) during local nighttime, and (3) enhancement of quasi-liquid layer and supercold liquid on the surface snow. Laboratory experiments conducted for earlier studies (e.g., Ge et al., 1998; Wise et al., 2009, Woods et al., 2010) revealed that chemical constituents with lower deliquescence relative humidity (DRH) can be localized in the outer layer (surface) around a solid core through phase transformation by deliquescence. Although relative humidity was minimal in the afternoon at Kohnen Station (Van As et al., 2005), the minimum relative humidity $(\sim 89 \%)$ was often higher than the deliquescence relative humidity (DRH) of plausible sea-salts. Some examples are the following: $\mathrm{NaCl}, 75 \%$ (Tang and Munkelwitz, 1993); $\mathrm{Na}_{2} \mathrm{SO}_{4}, 84 \%$ (Tang and Munkelwitz, 1994); $\mathrm{NaNO}_{3}, 75 \%$ (Tang and Munkelwitz, 1994); $\mathrm{MgCl}_{2} 6 \mathrm{H}_{2} \mathrm{O}, 33 \%$ (Kelly and Wexler, 2005); $\mathrm{MgSO}_{4}, 42 \%$ (Wang et al., 2008); and $\mathrm{KCl}, 84 \%$ (Tang, 1980). Most plausible sea-salts can be wholly deliquescent even under minimum relative humidity $(\sim 89 \%)$ on the Antarctic continent. Therefore, phase transformation by deliquescence / efflorescence might not be a key processes for $\mathrm{Mg}$ separation. With diurnal features of air temperature and relative humidity, re-condensation of water vapour on the snow surface during the local night-time might 
induce enhancement of supercooled water in nanometre-tomicrometre scales, a quasi-liquid layer, the re-freezing of water vapours and super-cold water such as is evident in a hoar formation. Particularly, re-freezing processes on surface snow might cause sea-salt fractionation as well as seawater freezing. Therefore, we propose that the repetition of a diurnal cycle of relative humidity and water sublimation under colder conditions can engender $\mathrm{Mg}$ separation on the surface snow on the Antarctic continent during summer.

\section{Concluding remarks}

Measurements of aerosol size distribution and direct aerosol sampling were made in the Queen Maud Land, Antarctica during the JASE traverse from 14 November 2007 until 24 January 2008. The OPC measurements revealed that aerosol number concentrations decreased gradually with latitude under background conditions (without drifting snow or strong winds) on the Antarctic continent during summer. The estimated aerosol mass concentrations in the size range larger than $0.3 \mu \mathrm{m}$ were $0.04-5.7 \mu \mathrm{g} \mathrm{m}^{-3}$. When strong winds and drifting snow occurred, aerosol number concentrations increased precipitously, especially in coarse mode. Air masses were isolated from the Antarctic coasts during the 5 days prior. Therefore, coarse aerosol particles (mainly sea-salt particles) might be released from the snow surface by blowing winds.

Single-particle analysis using SEM-EDX revealed that major aerosol particles were sea-salt particles, modified seasalt particles, and sulfate particles in coarse mode, and that the sulfate particles and modified sea-salt particles were dominant in fine mode during the JASE traverse. The Krich sulfates, Mg-rich sulfates, Ca-rich sulfates, and minerals were minor aerosol constituents in coarse and fine modes. Although $\mathrm{SO}_{4}^{2-}$ and $\mathrm{CH}_{3} \mathrm{SO}_{3}^{-}$contributed to sea-salt fractionation in coarse and fine modes over Syowa Station during summer (Hara et al., 2005, 2013), sea-salt particles were modified greatly with $\mathrm{SO}_{4}^{2-}$ and $\mathrm{NO}_{3}^{-}$in coarse mode, and dominantly with $\mathrm{SO}_{4}^{2-}$ in fine mode in this study. Precursors of particulate $\mathrm{NO}_{3}^{-}$(e.g., $\mathrm{HNO}_{3}$, and $\mathrm{NO}_{\mathrm{x}}$ ) might have originated from photochemical recycle of $\mathrm{NO}_{3}^{-}$in surface snow and subsequent oxidation in the atmosphere. Median atomic ratios of $\mathrm{Mg} / \mathrm{Na}$ in sea-salt particles and modified sea-salt particles in coarse and fine modes were often higher than the bulk seawater ratio. In addition, Mg-free sea-salt particles were identified on the Antarctic continent. Because the $\mathrm{Mg} / \mathrm{Na}$ ratio cannot be changed by sea-salt modification, the presence of Mg-rich sea-salt particles, Mg-free seasalt particles, and Mg-rich sulfate particles might be associated with sea-salt fractionation. $\mathrm{Mg}$-free sea-salt particles in coarse mode were often identified under conditions with strong winds and drifting snow. Therefore, fractionated seasalt particles were likely to have been released from the snow surface. This study proposed and assessed the hypothesis that sea-salt fractionation (Mg separation in sea-salts) occurs in surface snow on the Antarctic continent.

Acknowledgements. The JASE traverse was organized by several organizations both in Sweden and Japan. The National Institute of Polar Research (NIPR), Tokyo and the Swedish Polar Research Secretariat (SPRS) managed the logistics in Antarctica. Science management was a collaborative effort of NIPR, Stockholm University, the Royal Institute of Technology in Stockholm and individuals from several universities and institutes in Japan. The JASE traverse is one research project undertaken by the Japanese Antarctic Research Expedition "Studies on systems for climate change and ice sheet change, by introducing new observational methods and technologies". We thank JARE48 wintering members and JARE49 members for logistic support of the JASE traverse. Special thanks are extended to the logistics members, S. Gunnarsson, H. Kaneko, T. Karlberg, P. Ljusberg and K. Taniguchi and the medical doctors, S. Eriksson and N. Shiga, for their very generous support during the traverse. We thank anonymous referees for helpful and useful comments to improve our paper. This research was supported by the Swedish Research Council (VR) and by a Grant-in-Aid for Scientific Research (A) 20241007 from the Japan Society for the Promotion of Science (JSPS).

Edited by: J. Allan

\section{References}

Allison, I.: Surface climate of the interior of the Lambert Glacier basin, Antarctica, from automatic weather station data, Ann. Glaciol., 27, 515-520, 1998.

Artaxo, P., Rabello, M. L. C., Maenhaut, W., and van Grieken, R. Trace elements and individual particle analysis of atmospheric aerosols from the Antarctic Peninsula, Tellus, 44, 318-334, 1992.

Bertler, N., Mayewski, P. A., Aristarain, A., Barrett, P., Becagli, S., Bernardo, R. T., Cunde, X., Curran, M., Dahe, Q., Dixon, D., Ferron, F. A., Fischer, H., Frey, M., Frezzoi, M., Fundel, F., Genthon, C., Gragani, R., Hamilton, G., Handley, M., Hong, S., Isaksson, E., Jiawen, R., Kamiyama, K., Kanamori, S., Karkas, E., Karlöf, L., Kaspari, S., Kreutz, K., Kurbatov, A., Meyerson, E., Motoyama, H., Mulvaney, R., Mingjun, Z., Oerter, H., Osterberg, E., Proposito, M., Pyne, A., Ruth, U., Simoes, J. C., Smith, B., Sneed, S., Teinila, K., Traufetter, F., Udisti, R., Virkkula, A., Watanabe, O., Williamson, B., Wolff, E., and Zhongqin, L.: Snow Chemistry Across Antarctica, Ann. Glaciol., 41, 167-179, 2005.

Bodhaine, B. A.: Aerosol absorption measurements at Barrow, Mauna Loa and the South Pole, J. Geophys. Res., 100, 89678975, 1995.

Davis, D., Nowak, J. B., Chen, G., Buhr, M., Arimoto, R., Hogan, A., Eisele, F., Mauldin, L., Tanner, D., Shetter, R., Lefer, B., and McMurry, P.: Unexpected high levels of NO observed at South Pole, Geophys. Res. Lett., 28, 3625-3628, 2001.

Davis, D., Chen, G., Buhr, M., Crawford, J., Lenschow, D., Lefer, B., Shetter, R., Eisele, F., Mauldin, L., and Hogan, A.: South Pole $\mathrm{NO}_{\mathrm{x}}$ chemistry: an assessment of factors controlling variability and absolute levels, Atmos. Environ., 38, 5375-5388, 2004. 
Delmonte, B., Petit, J. R., Andersen, K. K., Basile-Doelsch, I., Maggi, V., and Ya Lipenkov, V.: Dust size evidence for opposite regional atmospheric circulation changes over east Antarctica during the last climatic transition, Clim. Dynam., 23, 427438, doi:10.1007/s00382-004-0450-9, 2004.

Delmonte, B., Petit, J. R., Basile-Doelsch, I., Jagoutz, E., and Maggi, V.: Late quaternary interglacials in East Antarctica from ice-core dust records, in: Developments in Quaternary Sciences, edited by: Sirocko, F., Claussen, M., Sánchez Goñi, M. F., and Litt, T., Elsevier, 7, 53-73, ISSN 1571-0866, ISBN 9780444529558, 2007.

Dibb, J., Huey, L., Slusher, D., and Tanner, D.: Soluble reactive nitrogen oxides at South Pole during isCAT 2000, Atmos. Environ., 38, 5399-5409, doi:10.1016/j.atmosenv.2003.01.001, 2004.

Ding, Z. J., Li, Y. G., Zeng, R. G., Mao, S. F., Zhang, P., and Zhang, Z. M.: Depth distribution functions of secondary electron production and emission, J. Surface Anal., 15, 249-253, 2009.

Draxler, R. R. and Rolph, G. D.: HYSPLIT (HYbrid Single-Particle Lagrangian Integrated Trajectory) Model access via NOAA ARL READY Website (http://ready.arl.noaa.gov/HYSPLIT. php), NOAA Air Resources Laboratory, Silver Spring, MD, 2013.

Eisele, F., Davis, D. D., Helmig, D., Oltmans, S. J., Neff, W., Huey, G., Tanner, D., Chen, G., Crawford, J., Arimoto, R., Buhr, M., Mauldin, L., Hutterli, M., Dibb, J., Blake, D., Brooks, S. B., Johnson, B., Roberts, J. M., Wang, Y., Tan, D., and Flocke, F.: Antarctic Tropospheric Chemistry Investigation (ANTCI) 2003 overview, Atmos. Environ., 42, 2749-2761, doi:10.1016/j.atmosenv.2007.04.013, 2008.

Frey, M. M., Savarino, J., Morin, S., Erbland, J., and Martins, J. M. F.: Photolysis imprint in the nitrate stable isotope signal in snow and atmosphere of East Antarctica and implications for reactive nitrogen cycling, Atmos. Chem. Phys., 9, 8681-8696, doi:10.5194/acp-9-8681-2009, 2009.

Fujita, S., Holmlund, P., Andersson, I., Brown, I., Enomoto, H., Fujii, Y., Fujita, K., Fukui, K., Furukawa, T., Hansson, M., Hara, K., Hoshina, Y., Igarashi, M., Iizuka, Y., Imura, S., Ingvander, S., Karlin, T., Motoyama, H., Nakazawa, F., Oerter, H., Sjöberg, L. E., Sugiyama, S., Surdyk, S., Ström, J., Uemura, R., and Wilhelms, F.: Spatial and temporal variability of snow accumulation rate on the East Antarctic ice divide between Dome Fuji and EPICA DML, The Cryosphere, 5, 1057-1081, doi:10.5194/tc-51057-2011, 2011.

Fujita, S., Fukui, K., Nakazawa, F., Enomoto, H., and Sugiyama, S.: Report of the Japanese-Swedish joint Antarctic traverse: II, Report of field expedition in 2007/2008 season, Submitted to Antarctic record, 2014 (in Japanese with English abstract).

Ge, Z., Wexler, A. S., and Johnston, M. V.: Deliquescence Behavior of Multicomponent Aerosols, J. Phys. Chem. A, 102, 173-180, 1998.

Geilfus, N.-X., Galley, R. J., Cooper, M., Halden, N., Hare, A., Wang, F., Søgaard, D. H., and Rysgaard, S.: Gypsum crystals observed in experimental and natural sea ice, Geophys. Res. Lett., 40, 6362—6367, doi:10.1002/2013GL058479, 2013.

Goldstein, J. I., Newbury, D. E., Joy, D. C., Lyman, C. E., Echlin, P., Lifshin, E., Sawyer, L., and Michael, J.: Chapter 6 Generation of $\mathrm{X}$-rays in the SEM specimen, in: Scanning Electron Microscopy and X-ray Micronalysis, 3, 271-296, Plenum Press, New York, 2003.
Hara, K., Kikuchi, T., Furuya, K., Hayashi, M., and Fujii, Y.: Characterization of Antarctic aerosol particles using laser microprobe mass spectrometry, Environ. Sci. Technol., 30, 385-391, 1995.

Hara, K., Osada, K., Hayashi, M., Matsunaga, K., Shibata, T., Iwasaka, Y., and Furuya, K.: Fractionation of inorganic nitrates in winter Arctic troposphere: Coarse aerosol particles containing inorganic nitrates, J. Geophy. Res., 104, 23671-23679, doi:10.1029/1999JD900348, 1999.

Hara, K., Osada, K., Nishita, C., Yamagata, S., Yamanouchi, T., Herber, A., Matsunaga, K., Iwasaka, Y., Nagatani, M., and Nakata, H.: Vertical variations of sea-salt modification in the boundary layer of spring Arctic during the ASTAR 2000 campaign, Tellus, 54B, 361-376, 2002.

Hara, K., Osada, K., Kido, M., Hayashi, M., Matsunaga, K., Iwasaka, Y., Yamanouchi, T., Hashida, G., and Fukatsu, T.: Chemistry of sea-salt particles and inorganic halogen species in the Antarctic regions: Compositional differences between coastal and inland stations, J. Geophys. Res., 109, D20208, doi:10.1029/2004JD004713, 2004.

Hara, K., Osada, K., Kido, M., Matsunaga, K., Iwasaka, Y., and Hashida, G.: Seasonal variations of sea-salt constituents and seasalt modification at Syowa station, Antarctica, Tellus, 57B, 230246, 2005.

Hara, K., Osada, K., Yabuki, M., Hashida, G., Yamanouchi, T., Hayashi, M., Shiobara, M., Nishita-Hara, C., and Wada, M.: Haze episodes at Syowa Station, coastal Antarctica: Where did they come from?, J. Geophys. Res., 115, D14205, doi:10.1029/2009JD012582, 2010a.

Hara, K., Hirasawa, N., Yamanouchi, T., Wada, M., Herber, A., and ANTSYO-II members: Spatial distributions and mixing states of aerosol particles in the summer Antarctic troposphere, Antarctic Record, 54, 704-730, 2010b (in Japanese with English abstract).

Hara, K., Osada, K., Nishita-Hara, C., Yabuki, M., Hayashi, M., Yamanouchi, T., Wada, M., and Shiobara, M.: Seasonal features of ultrafine particle volatility in the coastal Antarctic troposphere, Atmos. Chem. Phys., 11, 9803-9812, doi:10.5194/acp-11-98032011, 2011a.

Hara, K., Osada, K., Nishita-Hara, C., and Yamanouchi, T.: Seasonal variations and vertical features of aerosol particles in the Antarctic troposphere, Atmos. Chem. Phys., 11, 5471-5484, doi:10.5194/acp-11-5471-2011, 2011 b.

Hara, K., Osada, K., Yabuki, M., and Yamanouchi, T.: Seasonal variation of fractionated sea-salt particles on the Antarctic coast, Geophys. Res. Lett., 39, L18801, doi:10.1029/2012GL052761, 2012.

Hara, K., Osada, K., and Yamanouchi, T.: Tethered balloon-borne aerosol measurements: seasonal and vertical variations of aerosol constituents over Syowa Station, Antarctica, Atmos. Chem. Phys., 13, 9119-9139, doi:10.5194/acp-13-9119-2013, 2013.

Helmig, D., Johnson, B., Warshawsky, M., Morse, T., Neff, W., Eisele, F., and Davis, D. D.: Nitric Oxide in the Boundary-Layer at South Pole during the Antarctic Tropospheric Chemistry Investigation (ANTCI), Atmos. Environ., 42, 2817-2830, 2008.

Hirasawa, N., Nakamura, H., Motoyama, H., Hayashi, M., and Yamanouchi, T.: The role of synoptic-scale features and advection in prolonged warming and generation of different forms of precipitation at Dome Fuji station, Antarctica, following a prominent blocking event, J. Geophys. Res.-Atmos., 118, 6916-6928, doi:10.1002/jgrd.50532, 2013. 
Huey, L. G., Tanner, D. J., Slusher, D. L., Dibb, J. E., Arimoto, R., Chen, G., Davis, D., Buhr, M. P., Nowak, J. B., Mauldin III, R. L., Eisele, F. L., and Kosciuch, E.: CIMS measurements of $\mathrm{HNO}_{3}$ and $\mathrm{SO}_{2}$ at the South Pole during ISCAT 2000, Atmos. Environ., 38, 5411-5421, doi:10.1016/j.atmosenv.2004.04.037, 2004.

Iizuka, Y., Tsuchimoto, A., Hoshina, Y., Sakurai, T., Hansson, M., Karlin, T., Fujita, K., Nakazawa, F., Motoyama, H., and Fujita, S.: The rates of sea salt sulfatization in the atmosphere and surface snow of inland Antarctica, J. Geophys. Res., 117, D04308, doi:10.1029/2011JD016378, 2012.

Jones, A. E., Wolff, E. W., Ames, D., Bauguitte, S. J.-B., Clemitshaw, K. C., Fleming, Z., Mills, G. P., Saiz-Lopez, A., Salmon, R. A., Sturges, W. T., and Worton, D. R.: The multi-seasonal $\mathrm{NO}_{\mathrm{y}}$ budget in coastal Antarctica and its link with surface snow and ice core nitrate: results from the CHABLIS campaign, Atmos. Chem. Phys., 11, 9271-9285, doi:10.5194/acp-11-92712011, 2011.

Jourdain, B. and Legrand, M.: Seasonal variations of atmospheric dimethylsulfide, dimethylsulfoxide, sulfur dioxide, methanesulfonate, and non-sea-salt sulfate aerosols at Dumont d'Urville (coastal Antarctica) (December 1998 to July 1999), J. Geophys. Res., 106, 14391-14408, 2001.

Jourdain, B. and Legrand, M.: Year-round records of bulk and sizesegregated aerosol composition and $\mathrm{HCl}$ and $\mathrm{HNO}_{3}$ levels in the Dumont d'Urville (coastal Antarctica) atmosphere: Implications for sea-salt aerosol fractionation in the winter and summer, J. Geophys. Res., 107, 4645, doi:10.1029/2002JD002471, 2002.

Jourdain, B., Preunkert, S., Cerri, O., Castebrunet, H., Udisti, R., and Legrand, M.: Year-round record of size-segregated aerosol composition in central Antarctica (Concordia station): Implications for the degree of fractionation of sea-salt particles, J. Geophys. Res., 113, D14308, doi:10.1029/2007JD009584, 2008.

Junge, C. E.: Aerosols in "Air chemistry and radioactivity", Academic Press, 111-208, 1963.

Kahl, J., Harris, J., Herbert, G., and Olson, M.: Intercomparison of three long-range trajectory models applied to Arctic haze, Tellus B, 41B, 418, 524-536, 1989.

Kameda, T., Azuma, N., Furukawa, T., Ageta, Y., and Takahashi, S.: Surface mass balance, sublimation and snow temperatures at Dome Fuji Station, Antarctica, in 1995, Proc. NIPR Symp. Polar Meteorol. Glaciol., 11, 24-34, 1997.

Kelly, J. T. and Wexler, A. S.: Thermodynamics of carbonates and hydrates related to heterogeneous reactions involving mineral aerosol, J. Geophys. Res., 110, D11201, doi:10.1029/2004JD005583, 2005.

Kerminen, V. M., Teinilä, K., and Hillamo, R.: Chemistry of sea-salt particles in the summer Antarctic atmosphere, Atmos. Environ., 34, 2817-2825, 2000.

King, J. C., Argentini, S. A., and Anderson, P. S.: Contrasts between the summertime surface energy balance and boundary layer structure at Dome C and Halley stations, Antarctica, J. Geophys. Res., 111, D02105, doi:10.1029/2005JD006130, 2006.

Laskin, A., Moffet, R. C., Gilles, M. K., Fast, J. D., Zaveri, R. A., Wang, B., Nigge, P., and Shutthanandan, J.: Tropospheric chemistry of internally mixed sea salt and organic particles: Surprising reactivity of $\mathrm{NaCl}$ with weak organic acids, J. Geophys. Res., 117, D15302, doi:10.1029/2012JD017743, 2012.

Legrand, M., Sciare, J., Jourdain, B., and Genthon, C.: Subdaily variations of atmospheric dimethylsulfide, dimethylsulfoxide, methanesulfonate, and non-sea-salt sulfate aerosols in the atmospheric boundary layer at Dumont d'Urville (coastal Antarctica) during summer, J. Geophys. Res., 106, 409-14, 2001.

Legrand, M., Preunkert, S., Jourdain, B., and Aumont, B.: Yearround records of gas and particulate formic and acetic acids in the boundary layer at Dumont d'Urville, coastal Antarctica. J. Geophys. Res., 109, D06313, doi:10.1029/2003JD003786, 2004.

Marion, G. M. and Farren, R. E.: Mineral solubilities in the $\mathrm{Na}-\mathrm{K}-\mathrm{Mg}-\mathrm{Ca}-\mathrm{Cl}-\mathrm{SO}_{4}-\mathrm{H}_{2} \mathrm{O}$ system: a re-evaluation of the sulfate chemistry in the Spencer-Møller-Weare model, Geochim. Cosmochim. Acta, 63, 1305-1318, doi:10.1016/S00167037(99)00102-7, 1999.

Minikin, A., Legrand, M., Hall, J., Wagenbach, D., Kleefeld, C., Wolff, E., Pasteur, E., and Ducroz, F.: Sulfur-containing species (sulfate and methanesulfonate) in coastal Antarctic aerosol and precipitation, J. Geophys. Res., 103, 10975-10990, 1998.

Motoyama, H., Hirasawa, N., Satow, K., and Watanabe, O.: Seasonal variations in oxygen isotope ratios of daily collected precipitation and wind drift samples and in the final snow cover at Dome Fuji Station, Antarctica, J. Geophys. Res., 110, D11106, doi:10.1029/2004JD004953, 2005.

Mouri, H., Nagao, I., Okada, K., Koga, S., and Tanaka, H.: Individual-particle analyses of coastal Antarctic aerosols, Tellus, 51B, 603-611, 1999.

Neff, W., Helmig, D., Grachev, A., and Davis, D.: A study of boundary layer behavior associated with high NO concentrations at the South Pole using a minisodar, tethered balloon, and sonic anemometer, Atmos. Environ., 42, 2762-2779, doi:10.1016/j.atmosenv.2007.01.033, 2008.

Niemi, J., Tervahattu, H., Virkkula, A., Hillamo, R., Teinilä, K., Koponen, I., and Kulmala, M.: Continental Impact on Marine Boundary Layer Coarse Particles over the Atlantic Ocean between Europe and Antarctica, Atmos. Res , 75, 301-321, 2005.

Okada, K., Ikegami, M., Zaizen, Y., Makino, Y., Jensen, J. and Gras, J.: The mixture state of individual aerosol particles in the 1997 Indonesian haze episode, J. Aerosol Sci., 32, 1269-1279, doi:10.1016/S0021-8502(01)00062-3, 2001.

Okada, K., Ikegami, M., Zaizen, Y., Tsutsumi, Y., Makino, Y., Jensen, J., and Gras, J. L.: Submicrometer Sulfur-Rich Particles in the Middle Troposphere: Aircraft Observations from Australia to Japan, Atmos. Res., 88, 185-198, 2008.

Parungo, F., Ackerman, E., Caldwell, W., and Weickmann, H.: Individual Particle Analysis of Antarctic Aerosols, Tellus, 31, 521529, 1979.

Preunkert, S., Jourdain, B., Legrand, M., Udisti, R., Becagli, S., and Cerri, O.: Seasonality of sulfur species (dimethylsulfide, sulfate, and methanesulfonate) in Antarctica: Inland versus coastal regions, J. Geophys. Res., 113, D15302, doi:10.1029/2008JD009937, 2008.

Ram, M., Gayley, R., and Petit, J.-R.: Insoluble particles in Antarctic ice - Background aerosol size distribution and diatom concentration, J. Geophys. Res., 93, 8378-8382, doi:10.1029/JD093iD07p08378, 1988.

Rankin, A. M., Auld, V., and Wolff, E. W.: Frost flowers as a source of fractionated sea salt aerosol in the polar regions, Geophys. Res. Lett., 27, 3469-3472, doi:10.1029/2000GL011771, 2000.

Rankin, A. M., Wolff, E. W., and Martin, S.: Frost flowers: Implications for tropospheric chemistry and ice core interpretation, J Geophys. Res., 107, 4683, doi:10.1029/2002JD002492, 2002. 
Rankin, A. M. and Wolff, E. W.: A year-long record of sizesegregated aerosol composition at Halley, Antarctica, J. Geophys. Res., 108, 4775, doi:10.1029/2003JD003993, 2003.

Read, K. A., Lewis, A. C., Bauguitte, S., Rankin, A. M., Salmon, R. A., Wolff, E. W., Saiz-Lopez, A., Bloss, W. J., Heard, D. E., Lee, J. D., and Plane, J. M. C.: DMS and MSA measurements in the Antarctic Boundary Layer: impact of BrO on MSA production, Atmos. Chem. Phys., 8, 2985-2997, doi:10.5194/acp-82985-2008, 2008.

Reijmer, C. H. and van den Broeke, M. R.: Moisture source of precipitation in Western Dronning Maud Land, Antarctica, Antarct. Sci., 13, 210-220, doi:10.1017/S0954102001000293, 2001.

Reijmer, C. H., van den Broeke, M. R., and Scheele, M. P.: Air parcel trajectories and snowfall related to five deep drilling locations in Antarctica based on the ERA15 dataset, J. Climate, 15, 1957-1968, doi:10.1175/15200442(2002)015<1957:APTASR>2.0.CO;2, 2002.

Sato, K. and Hirasawa, N.: Statistics of Antarctic surface meteorology based on hourly data in 1957-2007 at Syowa Station, Polar Sci., 1, 1-15, 2007.

Savoie, D. L., Prospero, J. M., Larsen, R. J., and Saltzman, E. S.: Nitrogen and sulfur species in aerosols at Mawson, Antarctica, and their relationship to natural radionuclides, J. Atmos. Chem., 14, 181-204, 1992.

Savoie, D. L., Prospero, J. M., Larsen, R. J., Huang, F., Izaguirre, M. A., Huang, T., Snowdon, T. H., Custals, L., and Sanderson, C. G.: Nitrogen and sulfur species in Antarctic aerosols at Mawson, Palmer Station, and Marsh (King George Island), J. Atmos. Chem., 17, 95-122, 1993.

Stohl, A., Wotawa, G., and Seibert, P.: Interpolation errors in wind fields as a function of spatial and temporal resolution and their impact on different types of kinematic trajectories, J. Appl. Meteorol., 34, 2149-2165, 1995.

Suzuki, K., Yamanouchi, T., and Motoyama, H.: Moisture transport to Syowa and Dome Fuji stations in Antarctica, J. Geophys. Res., 113, doi:10.1029/2008JD009794, 2008.

Suzuki, K., Yamanouchi, T., Kawamura, K., and Motoyama, H.: The spatial and seasonal distributions of air-transport origins to the Antarctic based on 5-day backward trajectory analysis, Polar Sci., 7, 205-213, 2013.

Tang, I. N.: Deliquescence properties and particle size change of hygroscopic aerosols, in "Generation of aerosols and facilities for exposure experiments", edited by: K. Willeke, Chapter 7, 153167, Butterworth, Stoneham, Mass., 1980.

Tang, I. N. and Munkelwitz, H. R.: Composition and temperature dependence of the deliquescence properties of hygroscopic aerosols, Atmos. Environ, 27, 467-473, 1993.

Tang, I. N. and Munkelwitz, H. R.: Water activities, densities, and refractive indices of aqueous sulfates and sodium nitrate droplets of atmospheric importance, J. Geophys. Res., 99, 2156-2202, doi:10.1029/94JD01345, 1994.

Teinilä, K., Kerminen, V.-M., and Hillamo, R.: A study of sizesegregated aerosol chemistry in the Antarctic atmosphere, J. Geophys. Res., 105, 3893-3904, doi:10.1029/1999JD901033, 2000.
Udisti, R., Dayan, U., Becagli, S., Busetto, M., Frosini, D., Legrand, M., Lucarelli, F., Preunkert, S., Severi, M., Traversi, R., and Vitale, V.: Sea spray aerosol in central Antarctica. Present atmospheric behaviour and implications for paleoclimatic reconstructions, Atmos. Environ., 52, 109-120, 2012.

Van As, D., Van Den Broeke, M., and Van De Wal, R.: Daily cycle of the surface layer and energy balance on the high Antarctic Plateau, Antarct. Sci., 17, 121-133, 2005.

Wagenbach, D., Ducroz, F., Mulvaney, R., Keck, L., Minikin, A., Legrand, M. J., Hall, S., and Wolff, E. W.: Sea-salt aerosol in coastal Antarctic regions, J. Geophys. Res., 103, 10961-10974, 1998.

Wang, L.-Y., Ding, F., Zhang, Y.-H., Zhao, L.-J., and Hu, Y.A.: Anomalous hygroscopic growth of fine particles of $\mathrm{MgSO}_{4}$ aerosols investigated by FTIR/ATR spectroscopy, Spectrochimica Acta Part A, 71, 682-687, doi:10.1016/j.saa.2008.01.027, 2008.

Weller, R. and Wagenbach, D.: Year-round chemical aerosol records in continental Antarctica obtained by automatic samplings, Tellus, 59B, 755-765, 2007.

Weller, R., Jones, A. E., Wille, A., Jacobi, H.-W., McIntyre, H. P., Sturges, W. T., Huke, M., and Wagenbach, D.: Seasonality of reactive nitrogen oxides $\left(\mathrm{NO}_{\mathrm{y}}\right)$ at Neumayer Station, Antarctica, J. Geophys. Res., 107, 4673, doi:10.1029/2002JD002495, 2002.

Weller, R., Minikin, A., Wagenbach, D., and Dreiling, V.: Characterization of the inter-annual, seasonal, and diurnal variations of condensation particle concentrations at Neumayer, Antarctica, Atmos. Chem. Phys., 11, 13243-13257, doi:10.5194/acp11-13243-2011, 2011.

Wilson, T. R.: Salinity and the major elements of sea-water, in: Chemical Oceanography, edited by: Riley, J. P. and Skirrow, G., 365-413, Academic Press, San Diego, Calif., 1975.

Wise, M. E., Freney, E. J., Tyree, C. A., Allen, J. O., Martin, S. T., Russell, L. M., and Buseck P. R.: Hygroscopic behavior and liquid-layer composition of aerosol particles generated from natural and artificial seawater, J. Geophys. Res., 114, D03201, doi:10.1029/2008JD010449, 2009.

Woods, E., Chung, D., Lanney, H. M., and Ashwell, B. A.: Surface morphology and phase transitions in mixed $\mathrm{NaCl} / \mathrm{MgSO}_{4}$ aerosol particles, J. Phys. Chem. A, 114, 2837-2844, 2010.

Wouters, L., Artaxo, P., and van Grieken, R.: Laser Microprobe Mass Analysis of Individual Antarctic Aerosol Particles, Int. J. Environ. Anal. Chem., 38, 427-438, 1990.

Yamato, M., Iwasaka, Y., Ono, A., and Yoshida, M.: On the sulfate particles in the submicron size range collected at Mizuho Station and in east Queen Maud Land, Antarctica, Polar Meteorol. Glaciol., 1, 82-90, 1987a.

Yamato, M., Iwasaka, Y., Okada, K., Ono, A., Nishio, F., and Fukabori, M.: Evidence for the presence of submicron sulfuric acid particles in summer Antarctic atmosphere: Preliminary results, Proc. NIPR Symp. Polar Meteorol. Glaciol., 1, 74-81, 1987b. 